\title{
A systematic review of pregnant women with COVID-19 and their neonates
}

\author{
Mona Mirbeyk $^{1,2} \cdot$ Amene Saghazadeh ${ }^{1,2} \cdot$ Nima Rezaei $^{2,3,4,5}$
}

Received: 11 July 2020 / Accepted: 27 March 2021 / Published online: 2 April 2021

(c) The Author(s), under exclusive licence to Springer-Verlag GmbH Germany, part of Springer Nature 2021

\begin{abstract}
Background In December 2019, a novel coronavirus disease (COVID-19) emerged in Wuhan, China, with an incredible contagion rate. However, the vertical transmission of COVID-19 is uncertain.

Objectives This is a systematic review of published studies concerning pregnant women with confirmed COVID-19 and their neonates.

Search strategy We carried out a systematic search in multiple databases, including PubMed, Web of Science, Google Scholar, Scopus, and WHO COVID-19 database using the following keywords: (Coronavirus) OR (novel coronavirus) OR (COVID-19) OR (COVID19) OR (COVID 19) OR (SARS-CoV2) OR (2019-nCoV)) and ((pregnancy) OR (pregnant) OR (vertical transmission) OR (neonate) OR (newborn) OR (placenta) OR (fetus) OR (Fetal)). The search took place in April 2020.

Selection criteria Original articles published in English were eligible if they included pregnant patients infected with COVID19 and their newborns.

Data collection and analyses The outcomes of interest consisted of clinical manifestations of COVID-19 in pregnant patients with COVID-19 and also the effect of COVID-19 on neonatal and pregnancy outcomes.

Main results 37 articles involving 364 pregnant women with COVID-19 and 302 neonates were included. The vast majority of pregnant patients were in their third trimester of pregnancy, and only 45 cases were in the first or second trimester (12.4\%). Most mothers described mild to moderate manifestations of COVID-19. Of 364 pregnant women, 25 were asymptomatic at the time of admission. The most common symptoms were fever (62.4\%) and cough (45.3\%). Two maternal deaths occurred. Some pregnant patients $(12.1 \%)$ had a negative SARS-CoV-2 test but displayed clinical manifestations and abnormalities in computed tomography (CT) scan related to COVID-19. Twenty-two (6.0\%) pregnant patients developed severe pneumonia. Two maternal deaths occurred from severe pneumonia and multiple organ dysfunction. Studies included a total of 302 neonates from mothers with COVID-19. Of the studies that provided data on the timing of birth, there were 65 (23.6\%) preterm neonates. One baby was born dead from a mother who also died from COVID-19. Of the babies born alive from mothers with COVID-19, five newborns faced critical conditions, and two later died. A total of 219 neonates underwent nasopharyngeal specimen collection for SARS-CoV-2, of which 11 tested positive (5\%). Seventeen studies examined samples of the placenta, breast milk, umbilical cord, and amniotic fluid, and all tested negative except one amniotic fluid sample.

Conclusions A systematic review of published studies confirm that the course of COVID-19 in pregnant women resembles that of other populations. However, there is not sufficient evidence to establish an idea that COVID-19 would not complicate pregnancy.
\end{abstract}

Keywords COVID-19 $\cdot$ Immunity $\cdot$ Neonates $\cdot$ Pregnancy $\cdot$ SARS-CoV2 $\cdot$ Vertical transmission

Nima Rezaei

rezaei_nima@tums.ac.ir; rezaei_nima@yahoo.com

$1 \quad$ Systematic Review and Meta-Analysis Expert Group (SRMEG), Universal Scientific Education and Research Network (USERN), Tehran, Iran

2 Research Center for Immunodeficiencies, Children's Medical Center, Tehran University of Medical Sciences, Tehran, Iran
3 Department of Immunology, School of Medicine, Tehran University of Medical Sciences, Tehran, Iran

4 Network of Immunity in Infection, Malignancy and Autoimmunity (NIIMA), Universal Scientific Education and Research Network (USERN), Tehran, Iran

5 Children's Medical Center Hospital, Dr. Qarib St, Keshavarz Blvd, 14194 Tehran, Iran 


\section{Background}

The World Health Organization (WHO) announced the novel coronavirus disease (COVID-19) as a Pandemic on March 7, 2020, when the number of confirmed cases just exceeded 100,000 [1]. As of April 21, 2020, COVID-19 has reached all over the world, with about 180,000 deaths of a total of more than 2 million confirmed cases. Moreover, it seems there is an underestimation in the mortality rate of this infectious disease. Studies estimate the real mortality rate to be about $6 \%$ in China, rising to about $15 \%$ in other countries [2]. Therefore, COVID-19 is, in general, a lifethreatening condition.

COVID-19 can affect multiple organs and systems [3-11], although it mainly involves the respiratory system, where its involvement can cause a wide range of symptoms from a common cold to severe respiratory distress [12-15]. In particular, the disease is more severe and deadly in older age groups and people who have pre-existing comorbidity. The immunopathogenesis of the disease is not clear [16-21]. However, as for other infectious conditions, immune dysregulation might increase the risk of severe illness and death from COVID-19 [21-27].

Pregnancy is a particular condition that can have significant effects on the biological systems of a woman's body. Notably, pregnant women acquire changes so that their immune system will be able to tolerate pregnancy. These changes mostly place the maternal immune system under a down-regulated condition. As a result, pregnant women are generally considered vulnerable to infectious diseases.

Whereas its transmission mainly occurs through humanto-human contact, the novel coronavirus has shown its potential to transmit via multiple transmission routes [28] and affect both children and adults [13, 29]. It, however, remained unclear whether or not this potentially fatal virus can vertically be transmitted and what are the possible effects of the disease on the pregnancy outcomes.

\section{Methods}

The present systematic review was developed according to the preferred reporting items for systematic reviews and meta-analyses (PRISMA) statement [14]. Before the study begins, the authors developed the study protocol that is available on request.

\section{Literature search}

We carried out a systematic search in multiple databases, including PubMed, Web of Science, Google Scholar,
Scopus, and WHO COVID-19 database using the following keywords: (Coronavirus) OR (novel coronavirus) OR (COVID-19) OR (COVID19) OR (COVID 19) OR (SARSCoV2) OR (2019-nCoV)) and ((pregnancy) OR (pregnant) OR (vertical transmission) OR (neonate) OR (newborn) OR (placenta) OR (fetus) OR (Fetal)). The search took place in April 2020 (Fig. 1).

\section{Selection criteria}

We sought studies that investigated the potential effect of COVID-19 on pregnancy and neonatal health. Original articles published in English were eligible if they included pregnant patients infected with COVID-19 and their newborns. The outcomes of interest consisted of clinical manifestations of COVID-19 in pregnant patients with COVID-19 and also, the effect of COVID-19 on neonatal and pregnancy outcomes.

\section{Data extraction}

For pregnant women infected with COVID-19, we extracted the following data: article title, author, study type, country, number of pregnant women with COVID-19, clinical manifestations of disease in pregnant women, the trimester of pregnancy, diagnostic technique, potential complications related to COVID-19, delivery, and the maternal outcome(s) of COVID-19. For neonates born from mothers with COVID-19, data on the article title, author, study type, country, number of neonates, neonatal maturity, clinical presentation, neonatal complications, a diagnostic test for COVID-19, Apgar score, and neonatal outcome were extracted. Finally, for pregnancy outcomes, we collected data on the article title, author, study type, country, placental test for viral nucleic acid, and pregnancy complications.

\section{Results}

\section{Literature search}

The systematic search yielded a total of 1068 search results, of which 785 discrete records remained for screening after removing duplicates. During title and abstract screening, we selected 48 articles for detailed review. In the detailed review process, we excluded thirteen articles with the following reasons for exclusion: seven articles not provided data on pregnant patients or neonatal outcomes [28, 30-35], three studies lacked data on neonates or vertical transmission [36-38], one study reported a 17-day neonate who had exposure to parents complaining of fever and cough [39], one study was not original research [40], and the full-text was not available for one article [41]. 


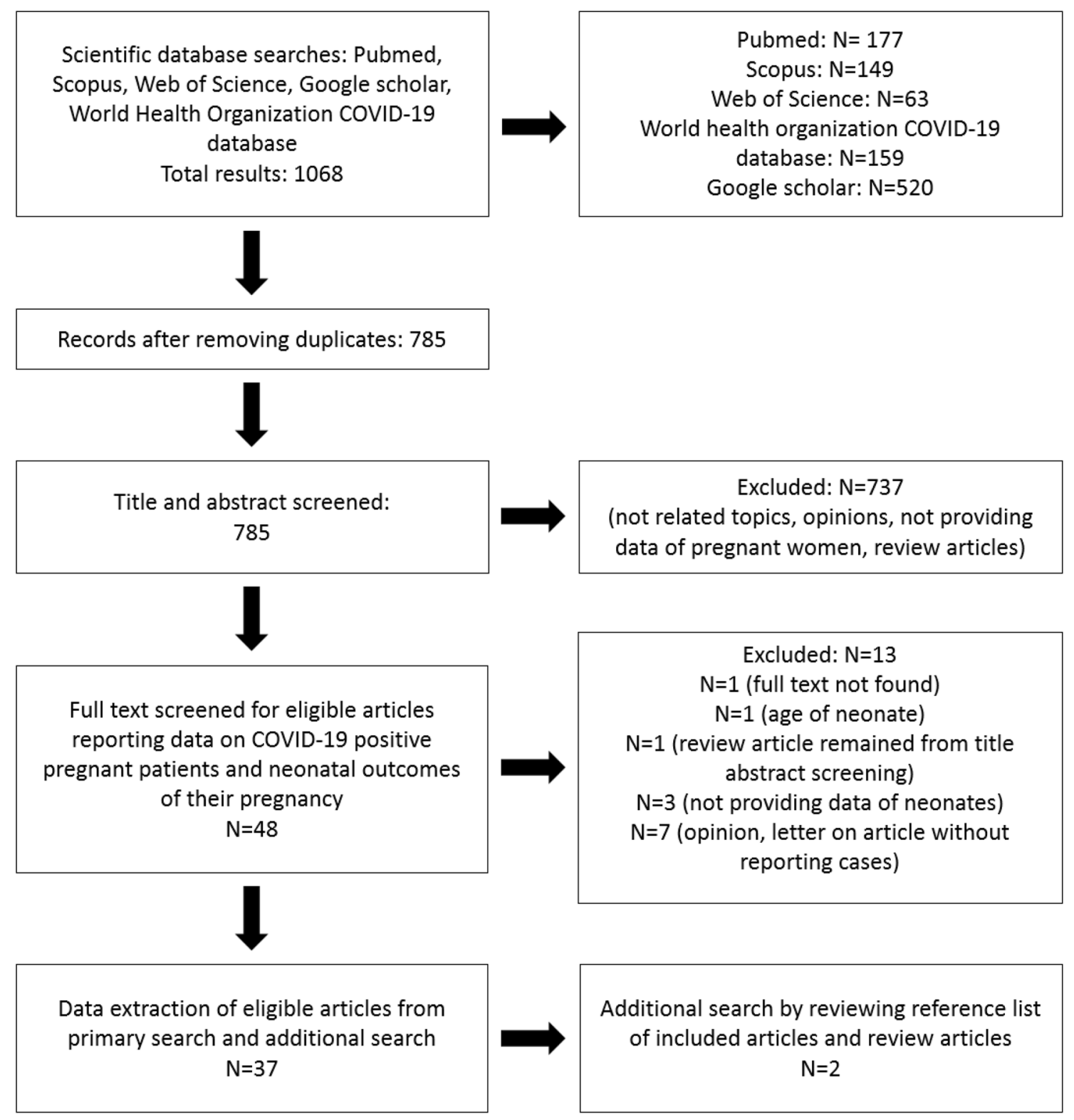

Fig. 1 PRISMA flowchart of the literature search

\begin{abstract}
Also, we carried out an additional search through reviewing reference lists of 35 included articles from systematic search and related review articles and found two additional articles [42, 43]. Finally, a total number of 37 studies, including case reports and case series, were eligible to be included in this systematic review [42-76]. Tables 1, 2, 3 provide an overview of the characteristics of the included studies. Below is a narrative synthesis of studies that included pregnant women with confirmed COVID-19 and their neonates.
\end{abstract}

\section{Clinical presentation of COVID-2019 in pregnant women}

Of 37 studies, two provided no data on clinical symptoms of pregnant patients [43, 44]. A total of 364 pregnant women was, thus, included in the data synthesis of clinical manifestations of COVID-19 in pregnant women.

Of 364 pregnant women, 25 were asymptomatic at the time of admission. The most common symptoms were fever (62.4\%) and cough (45.3\%). The other common symptoms 


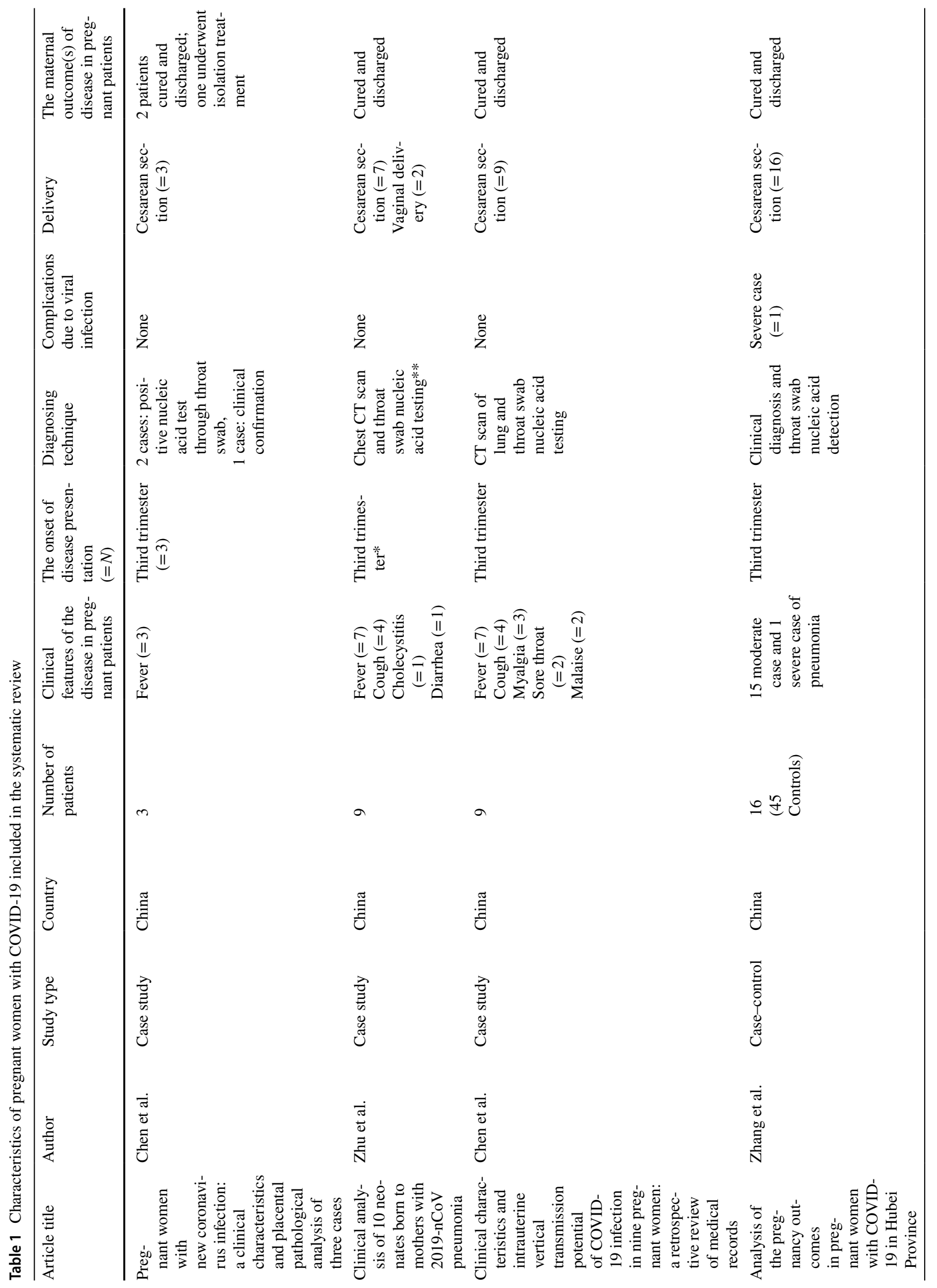




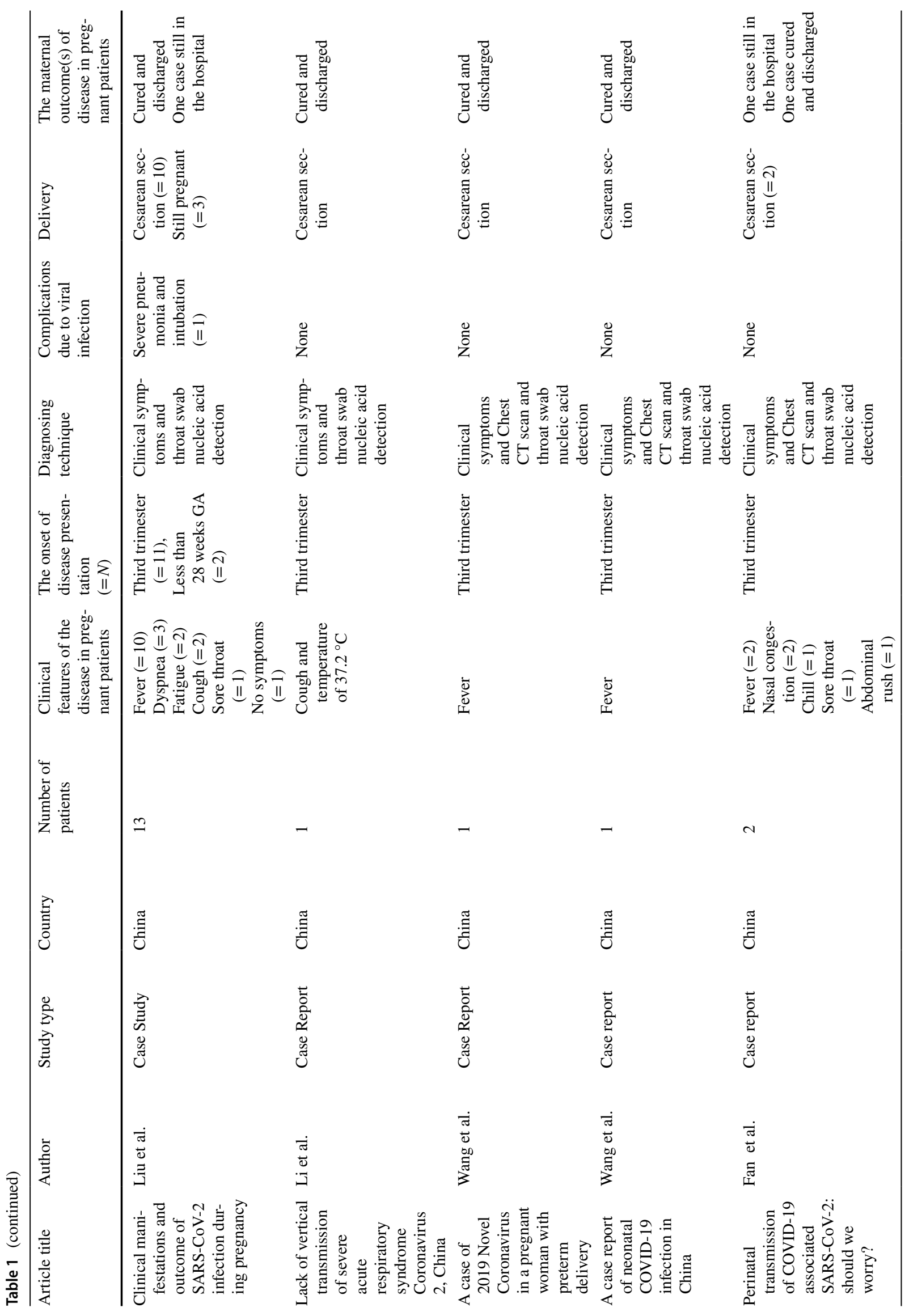




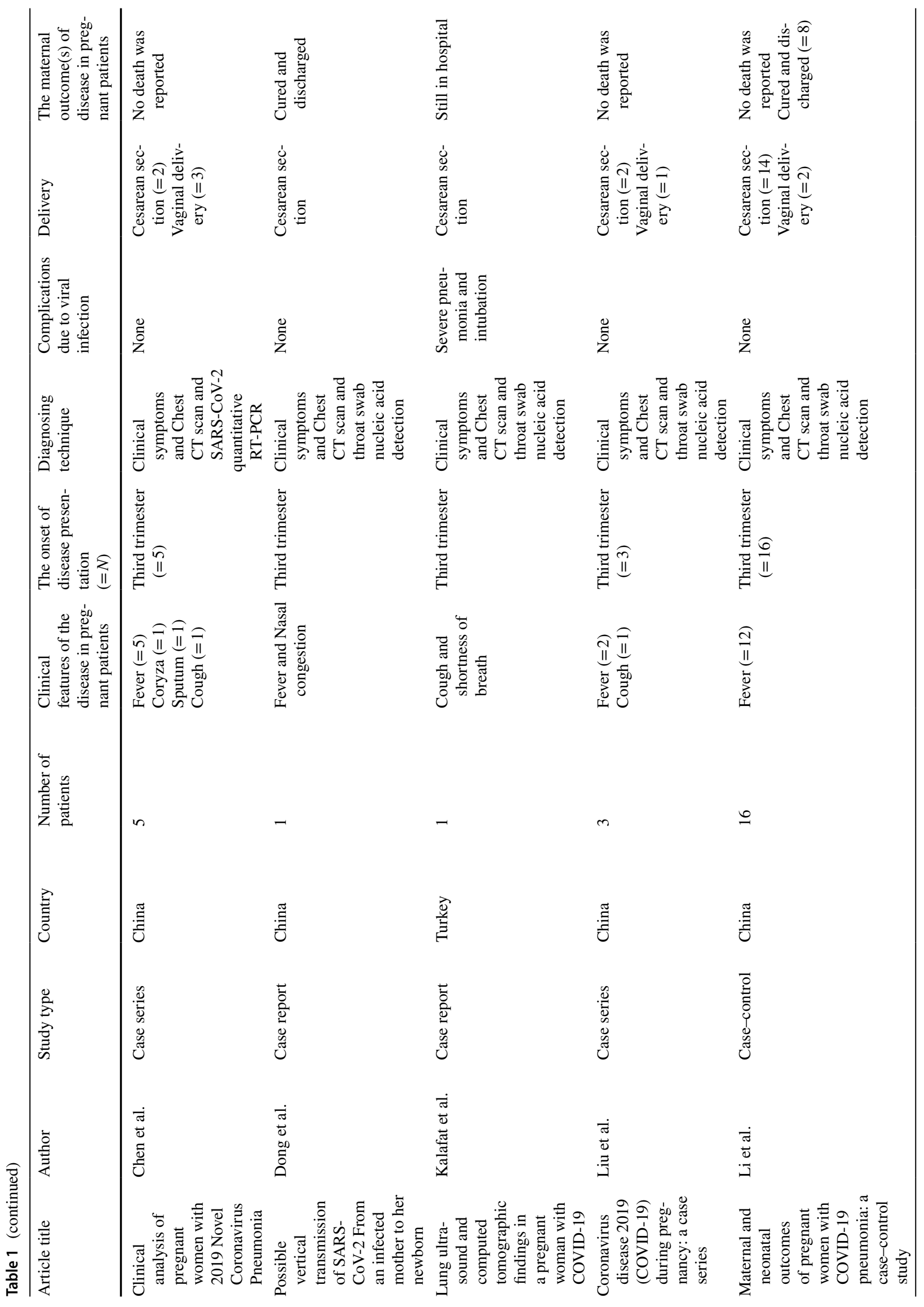




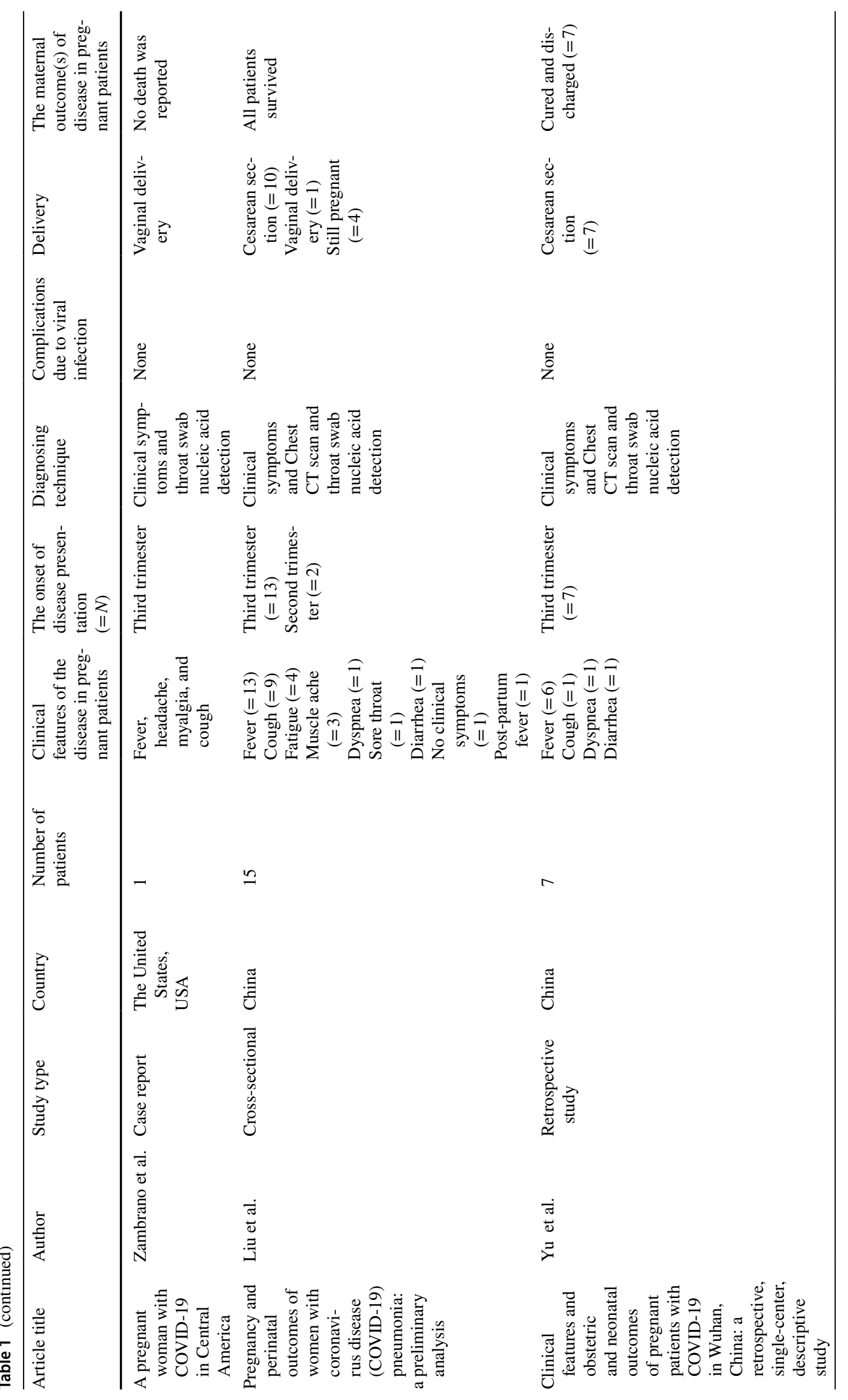




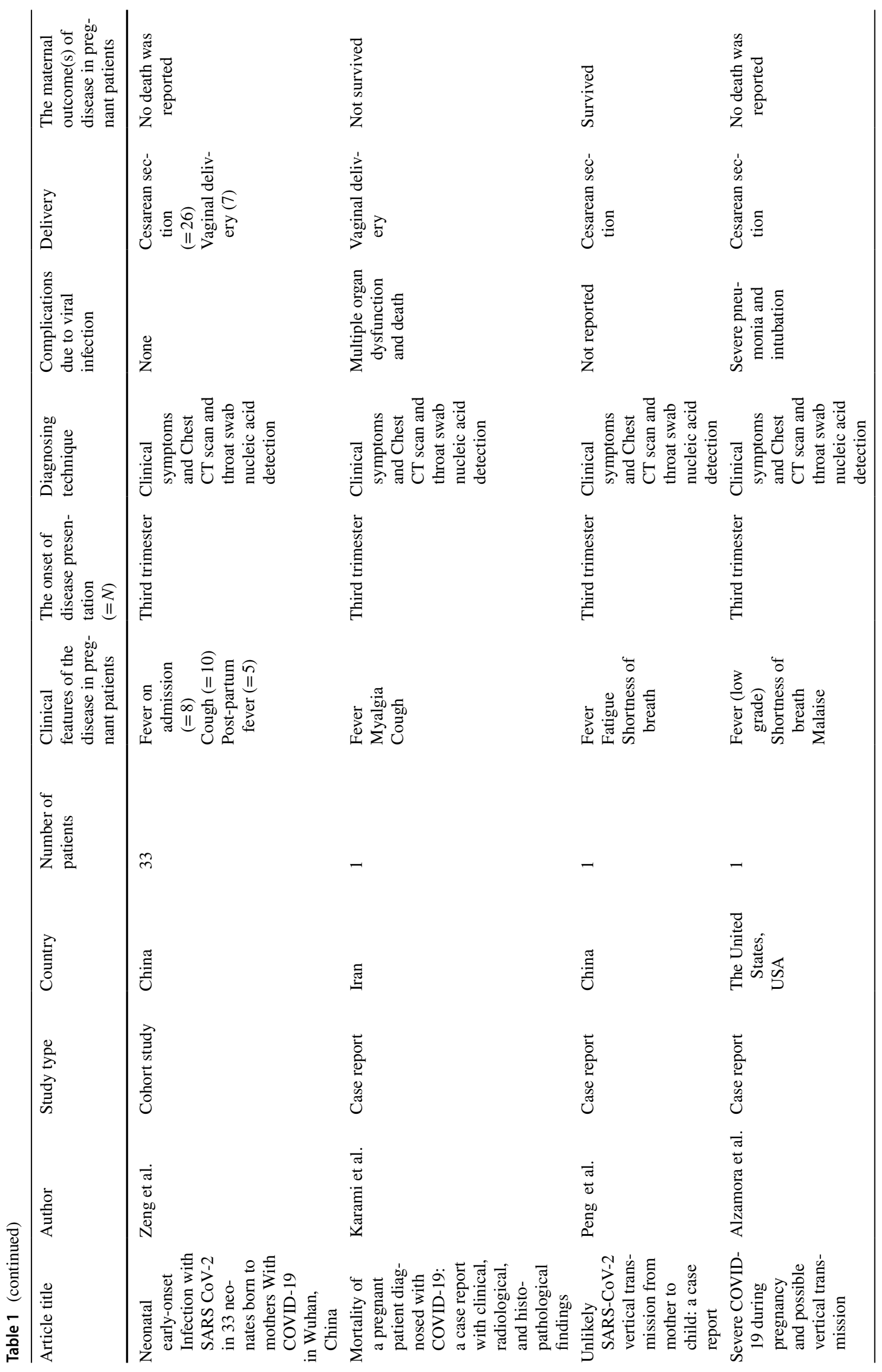




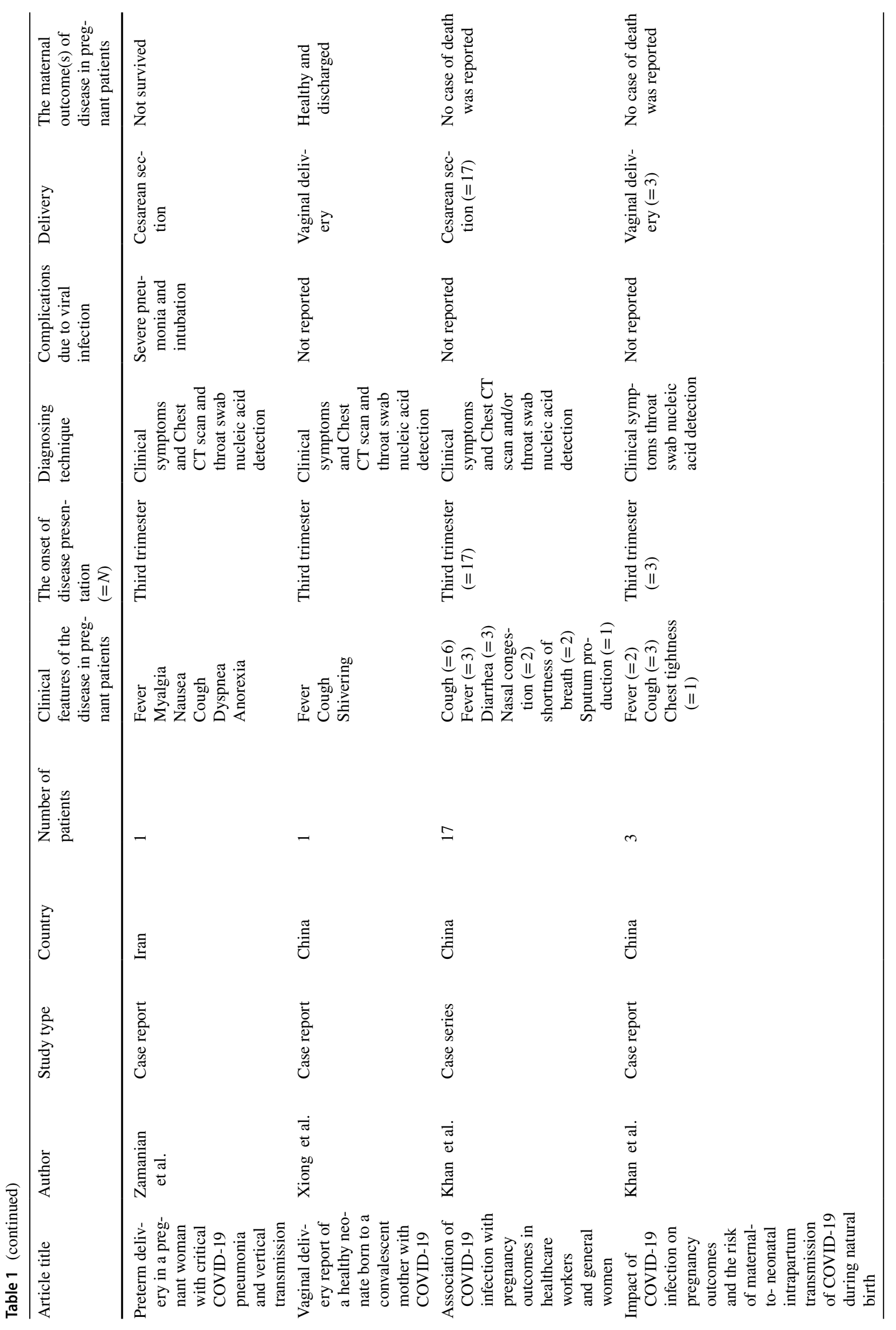




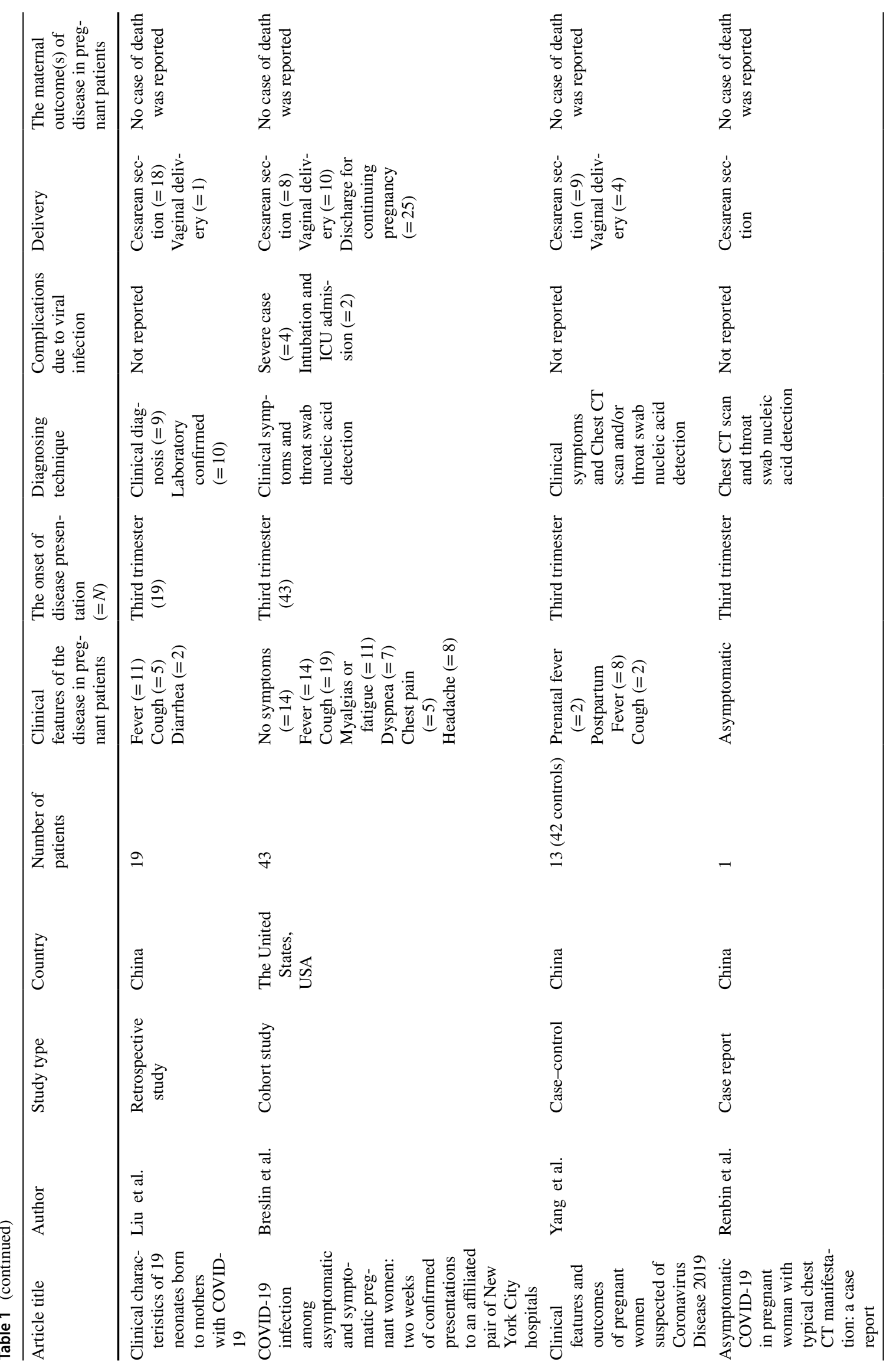




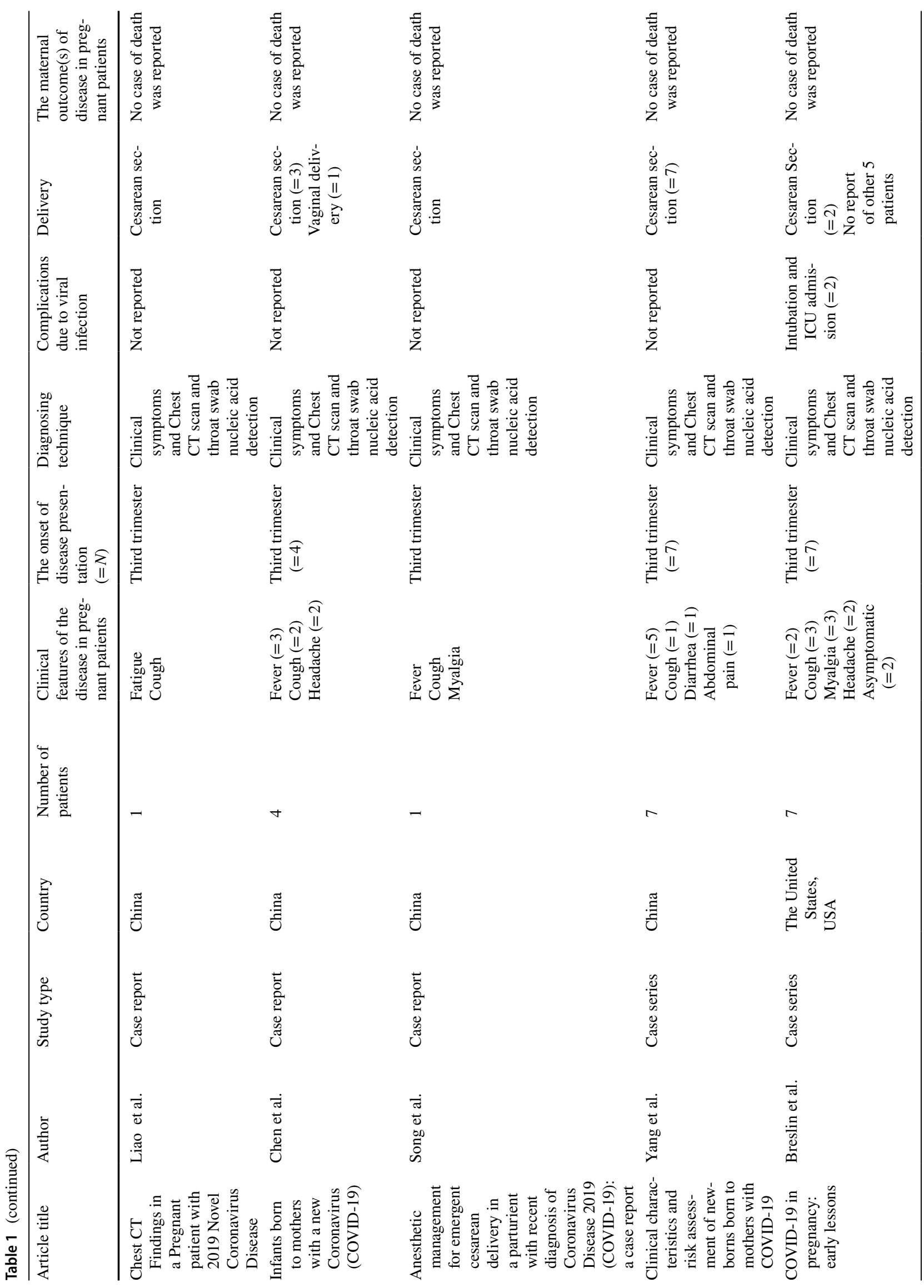




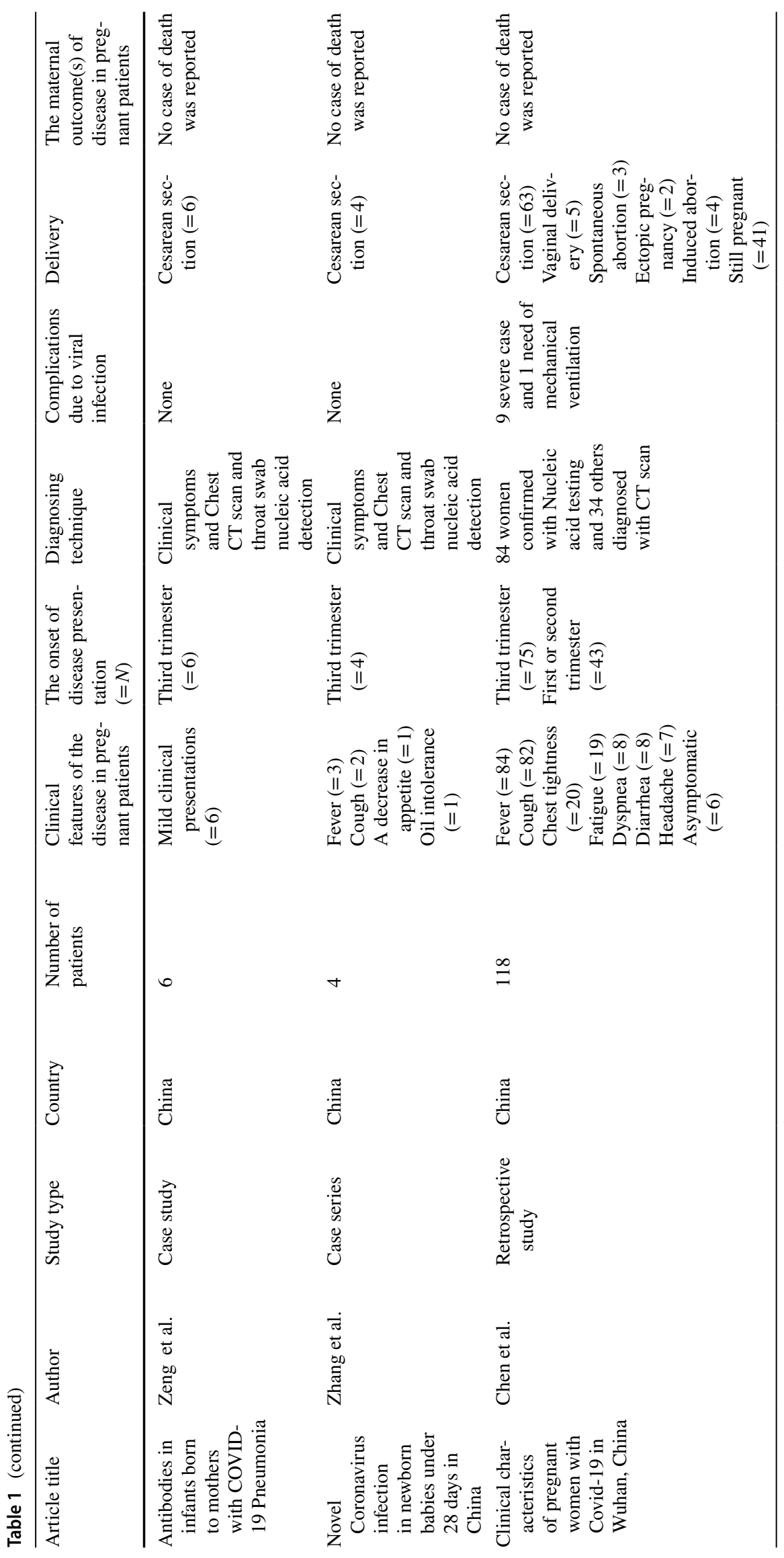




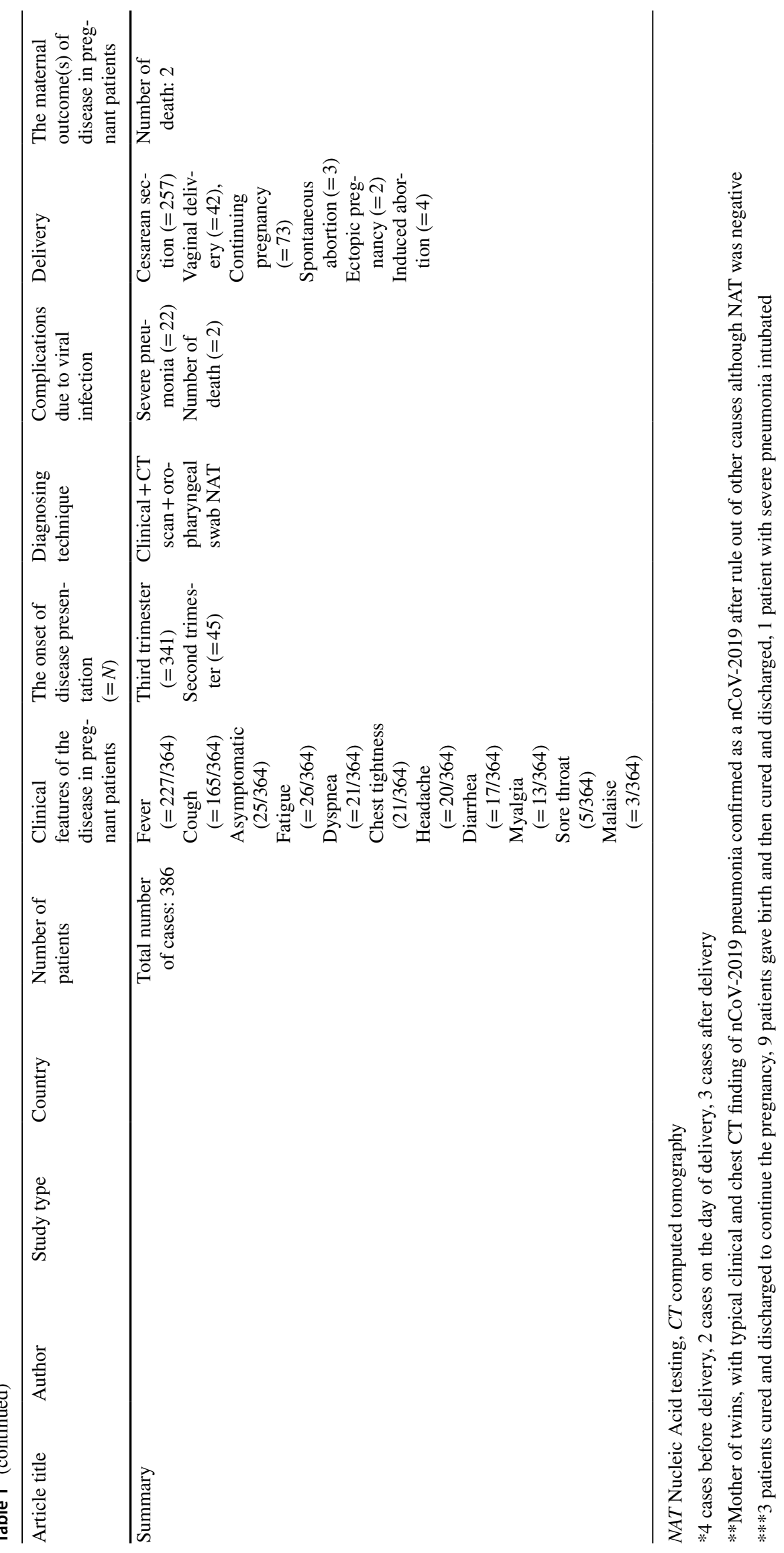




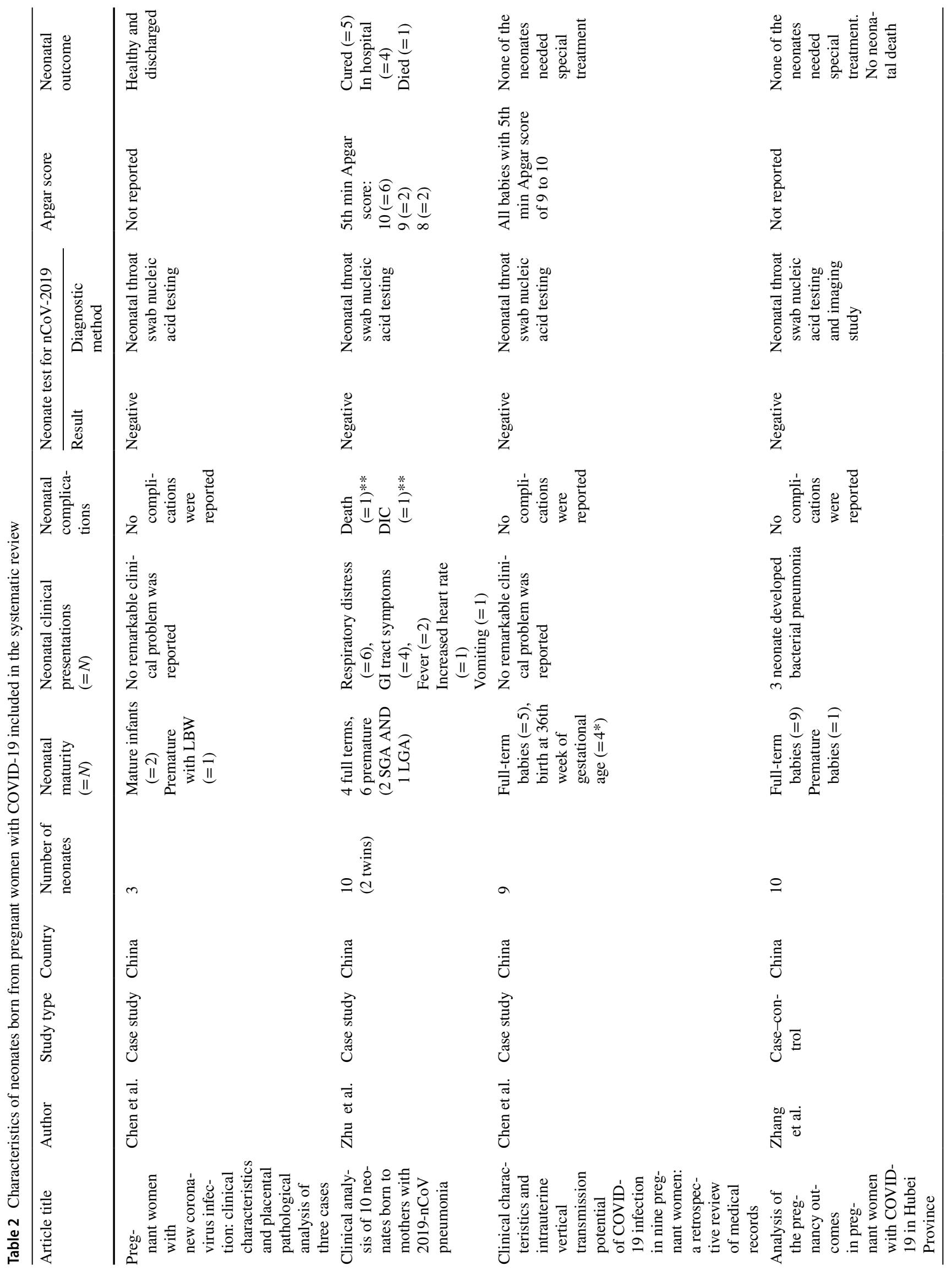




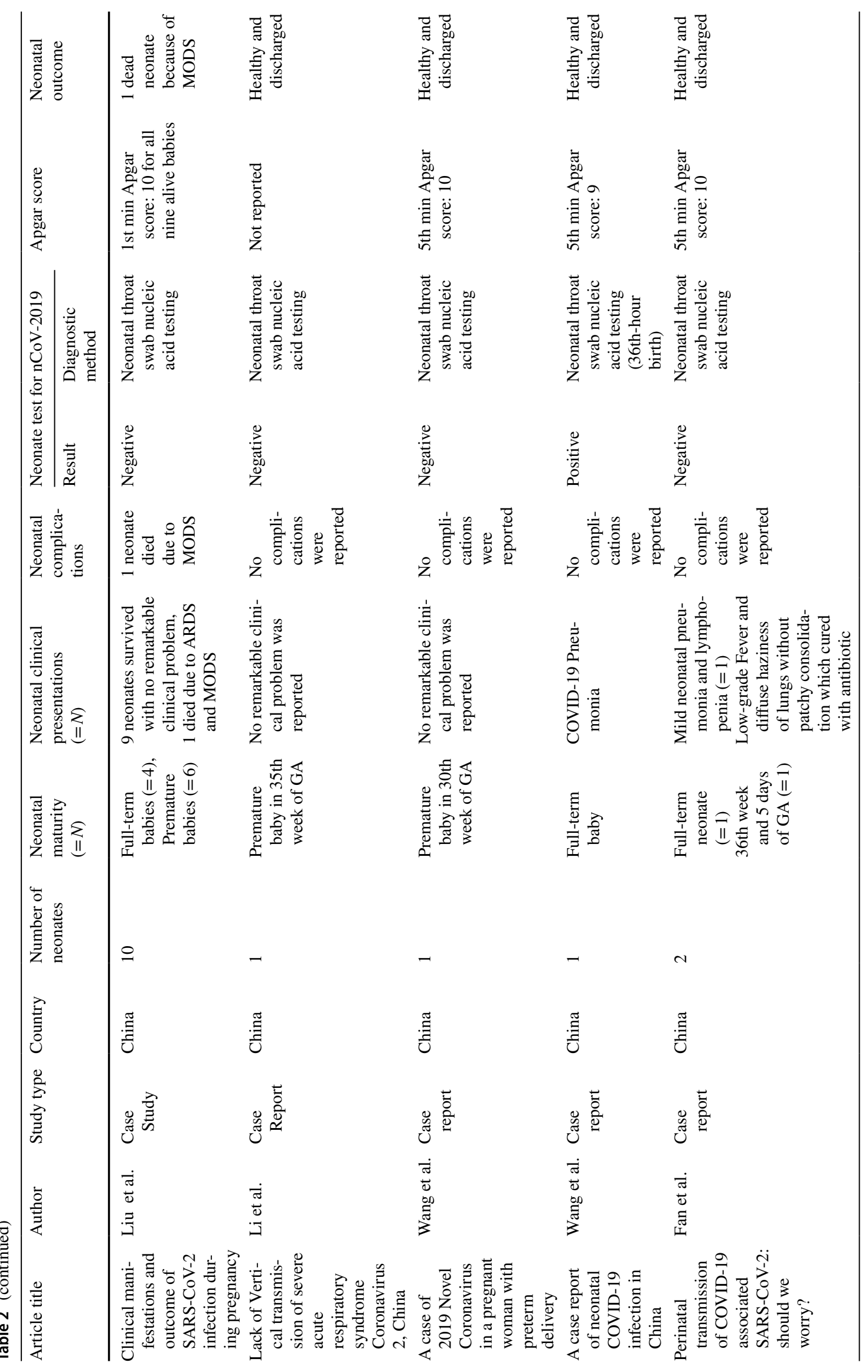




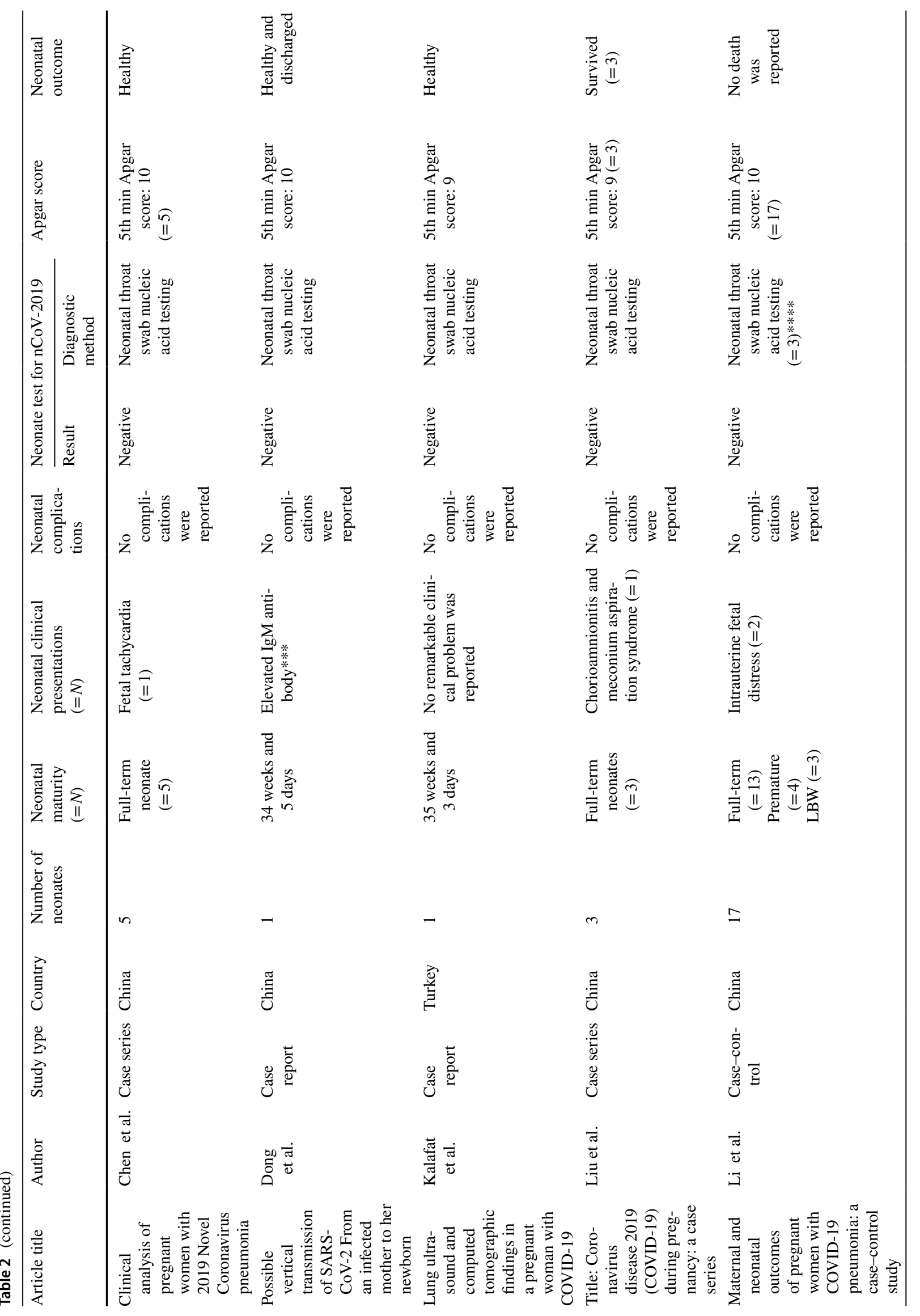




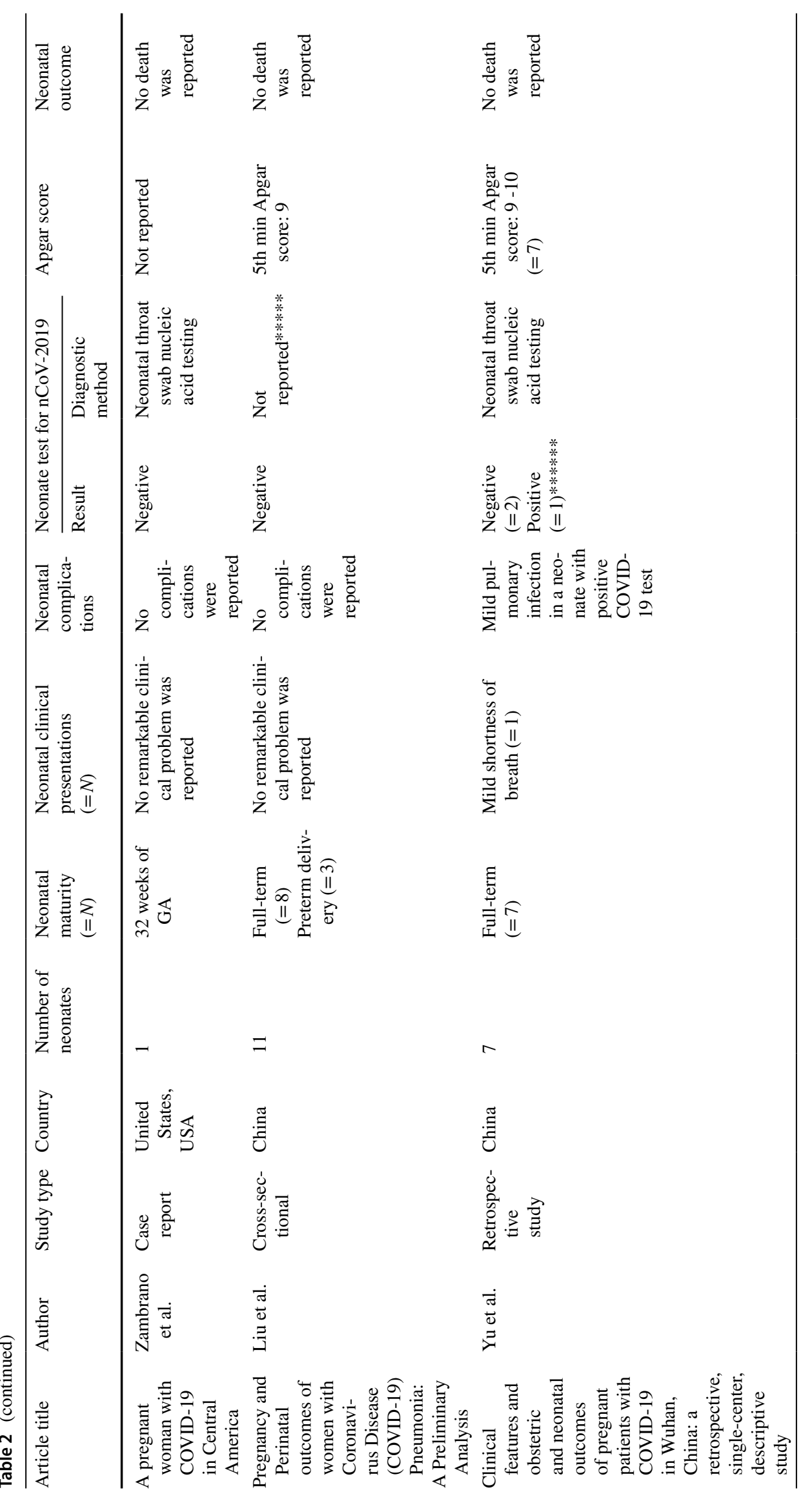




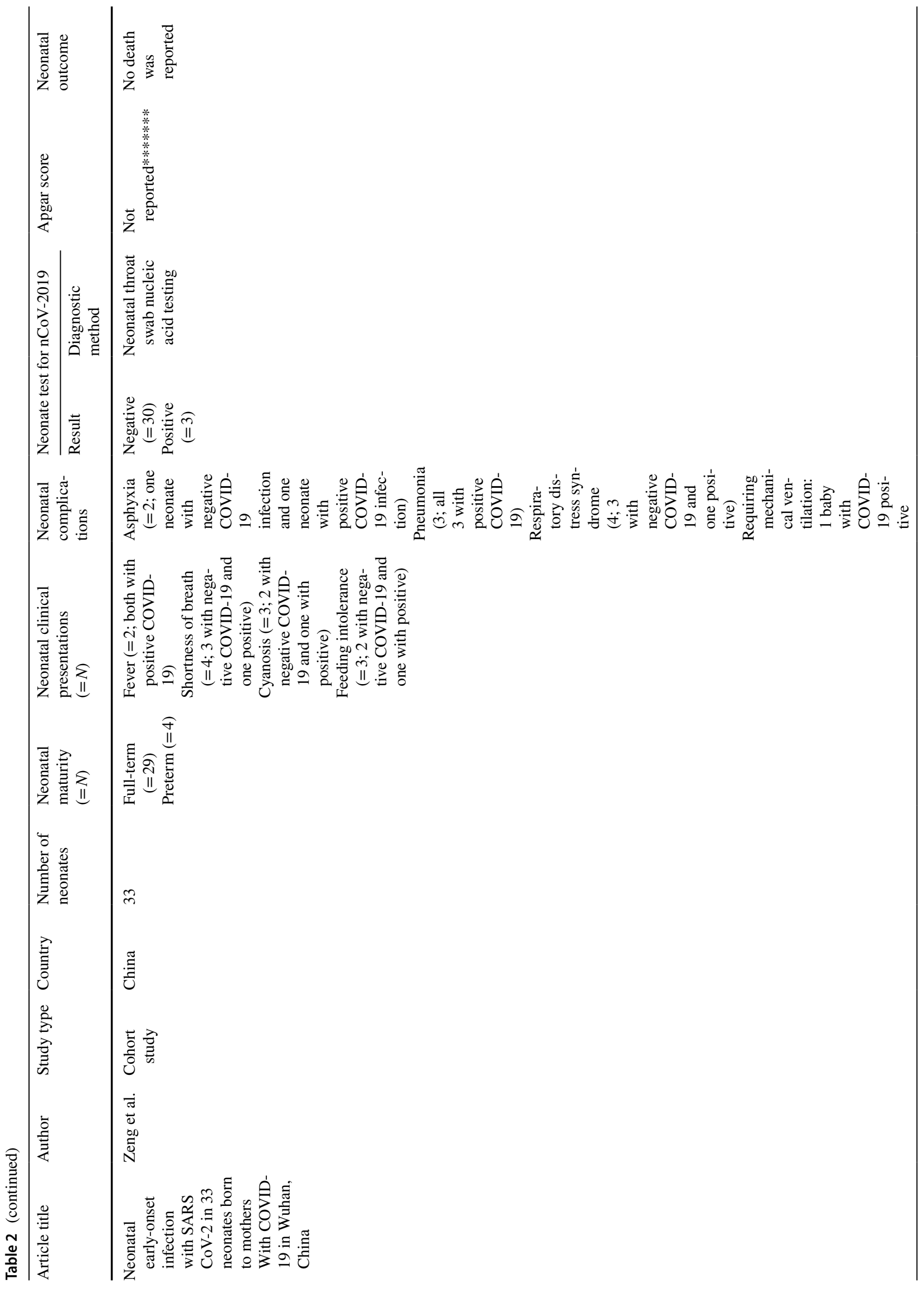




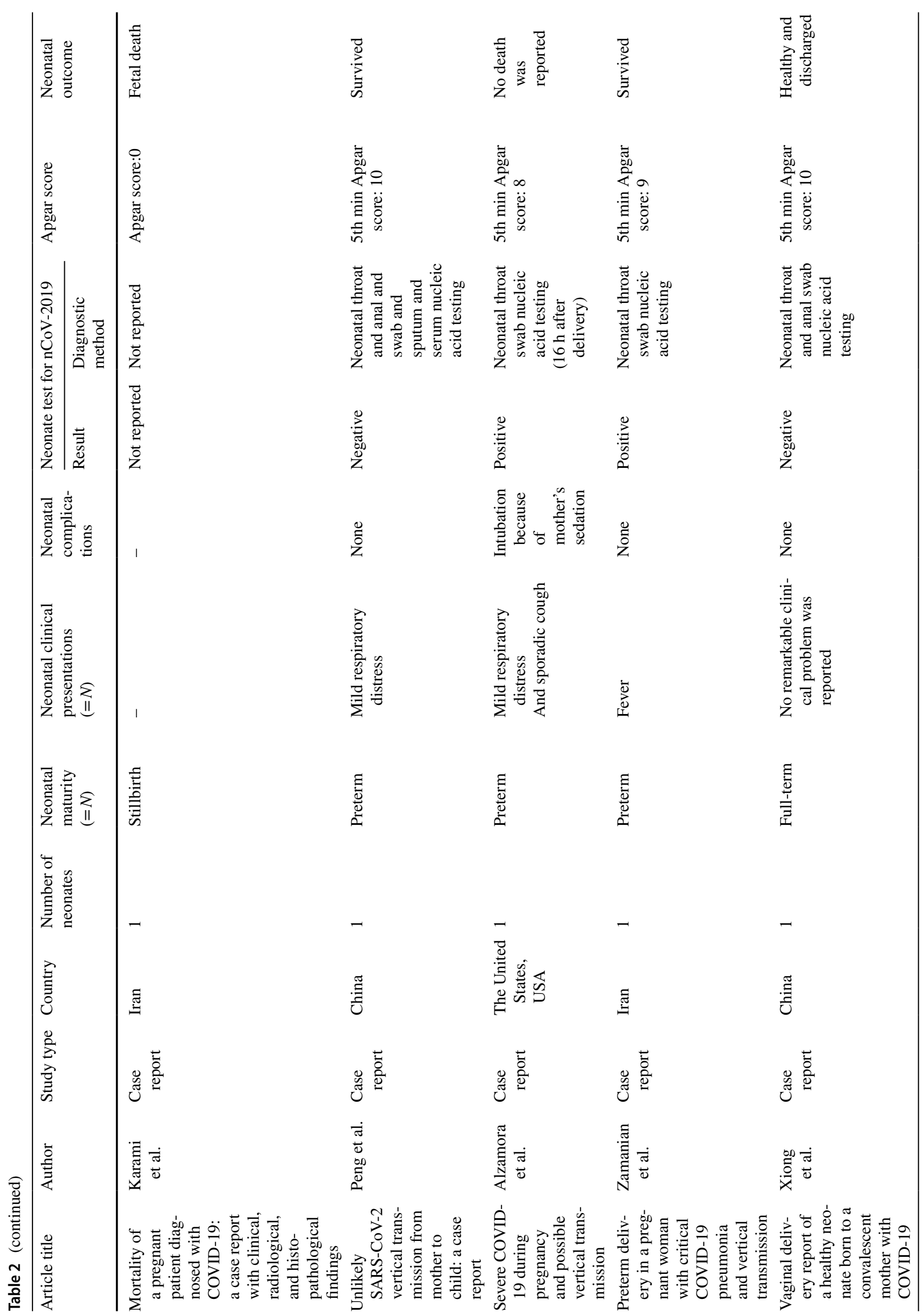




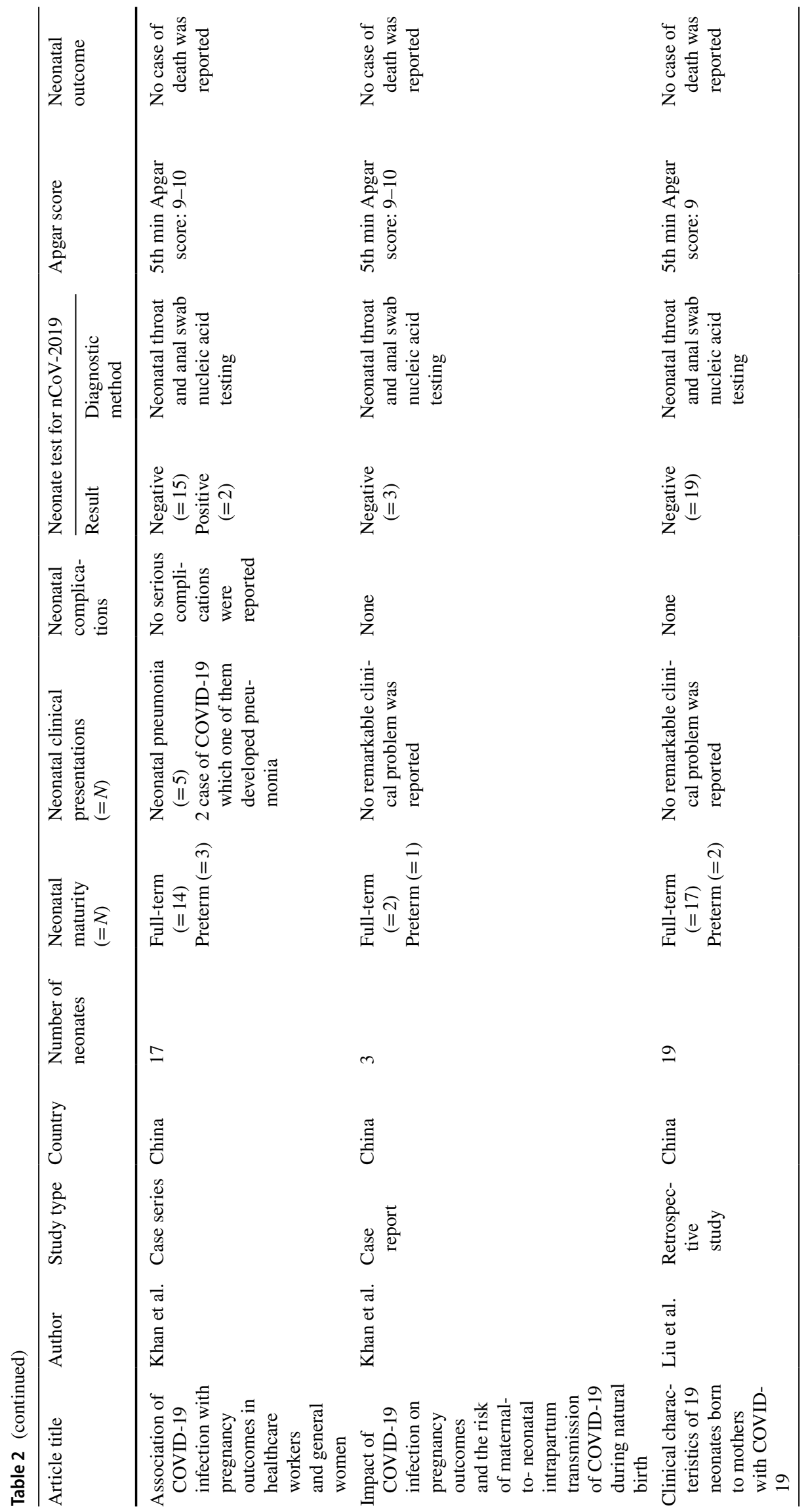




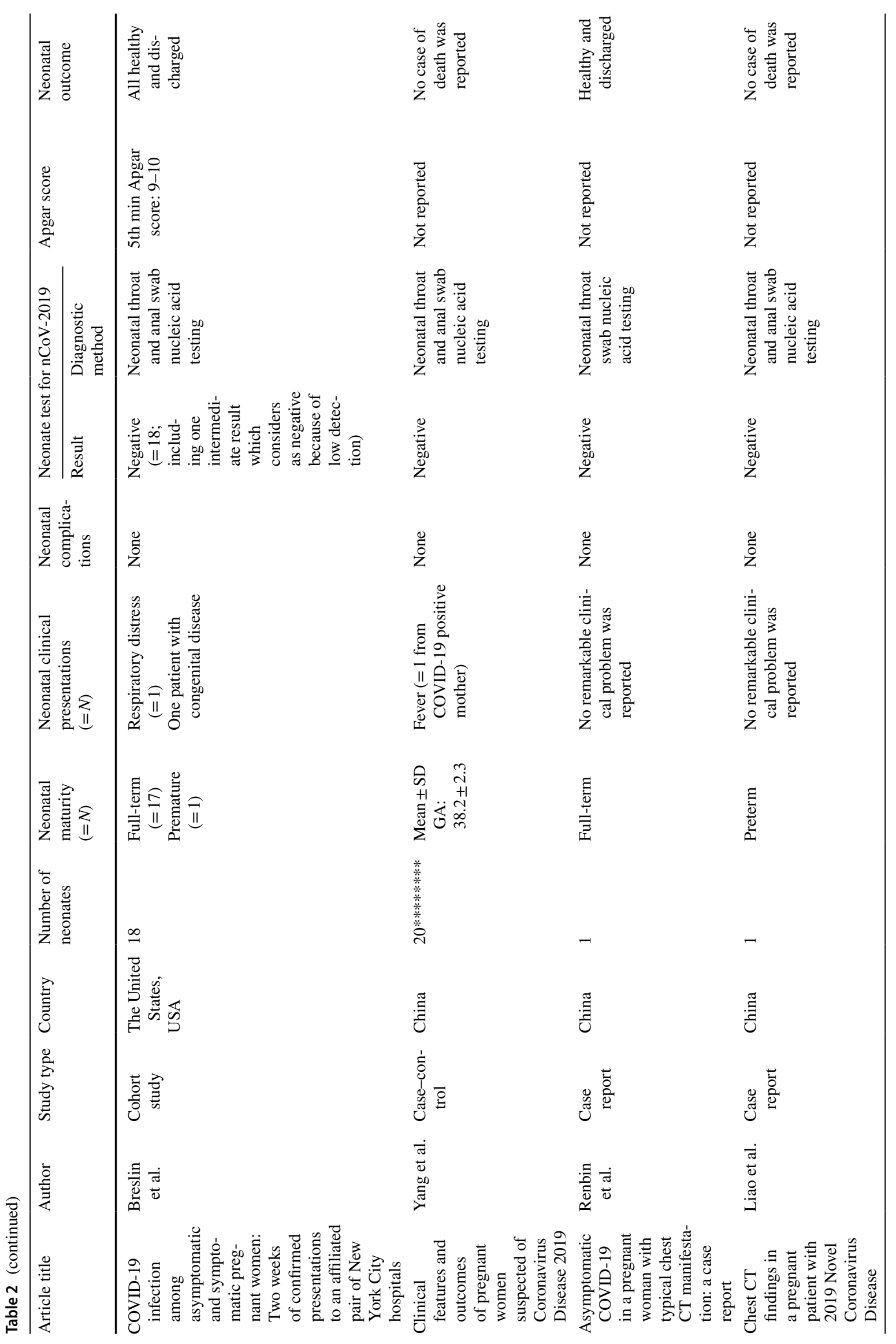




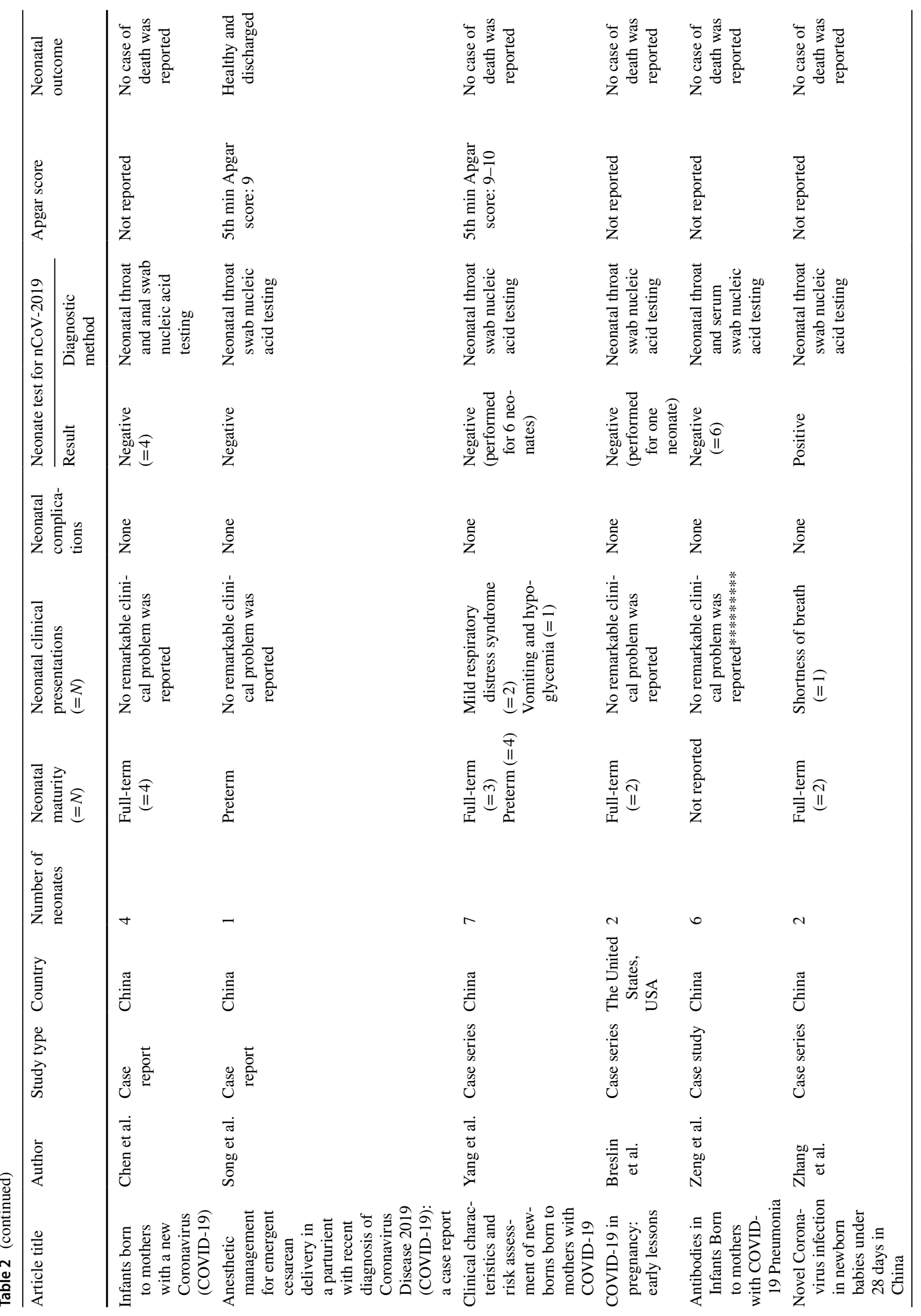




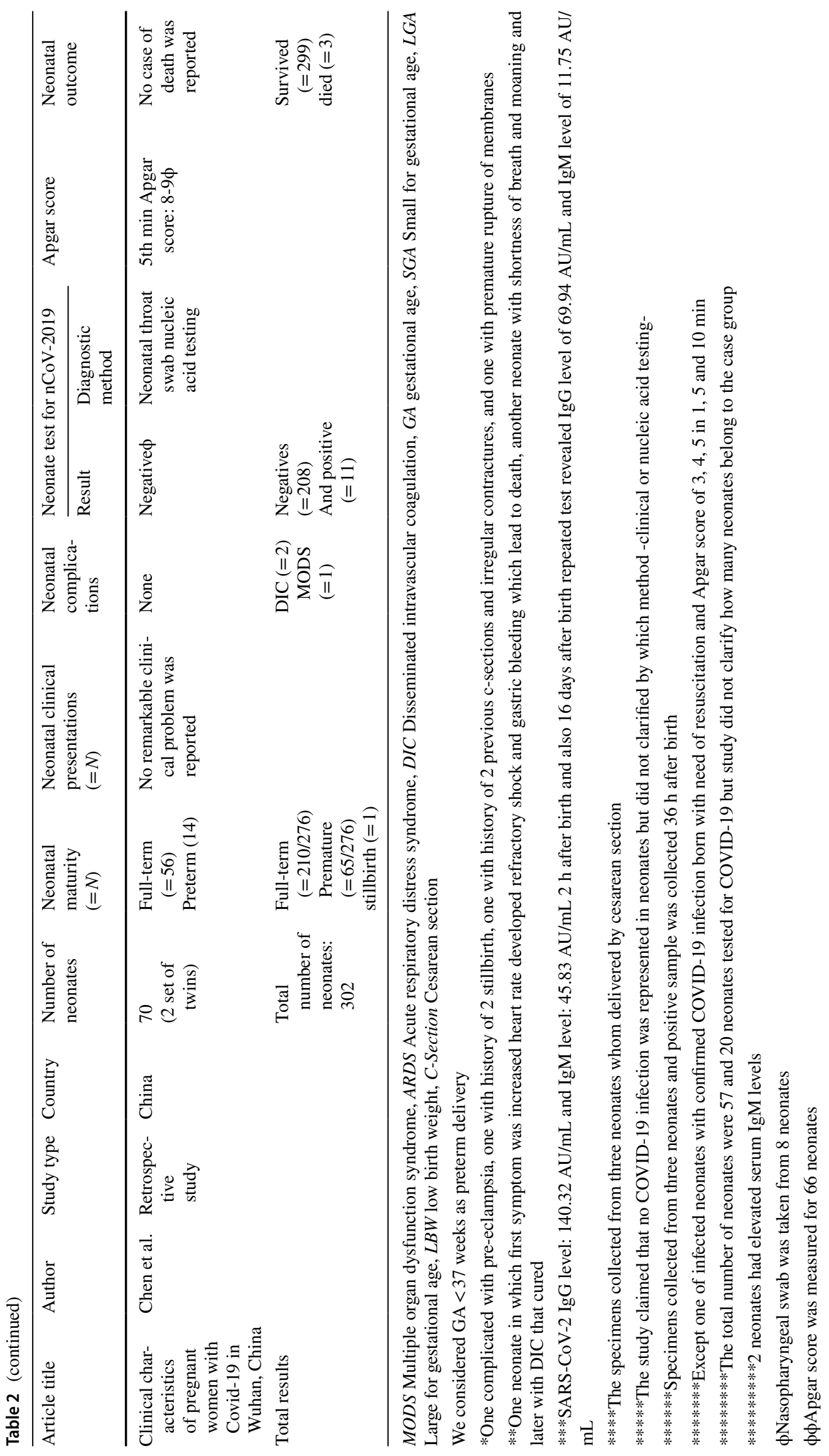




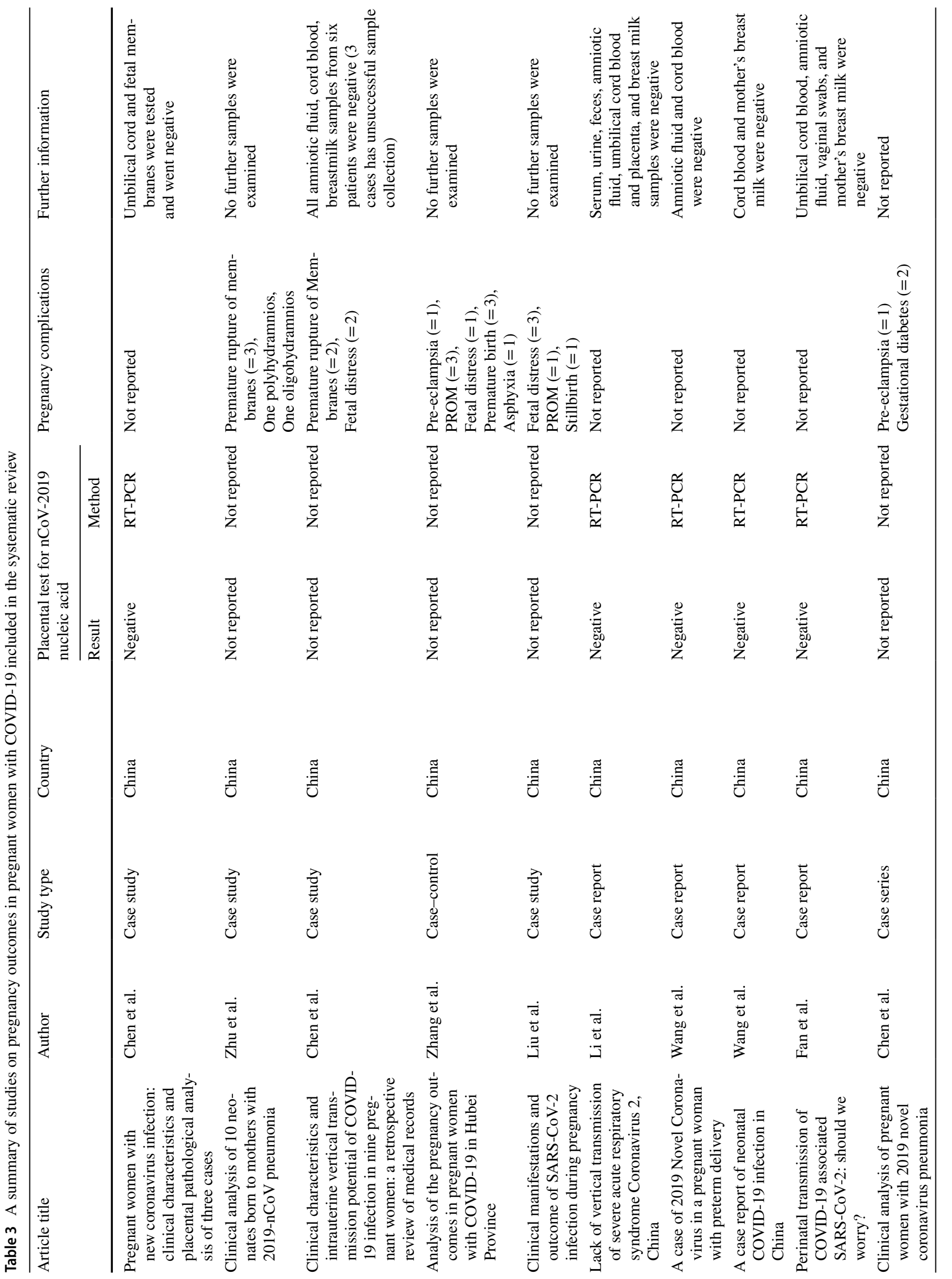




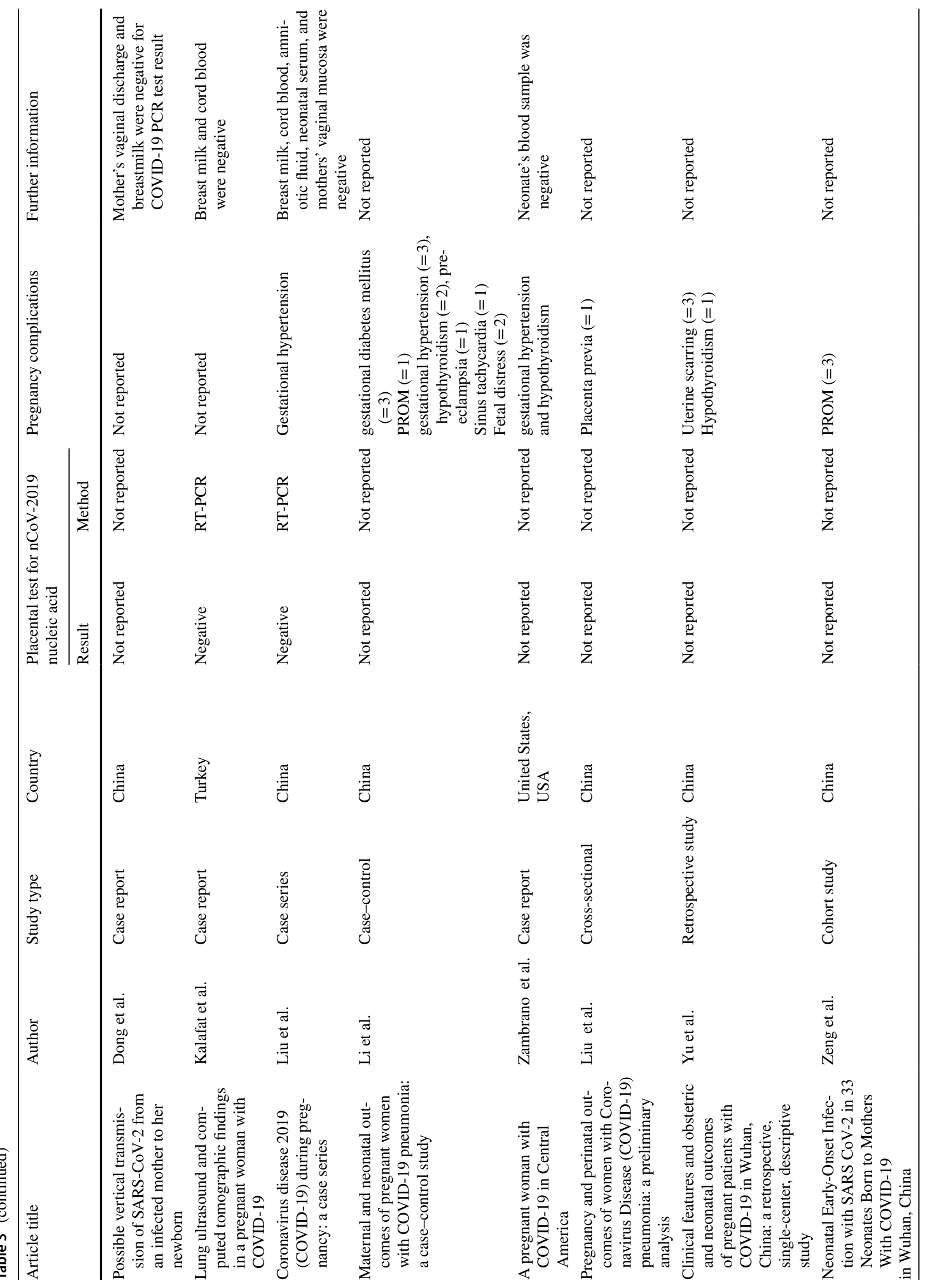




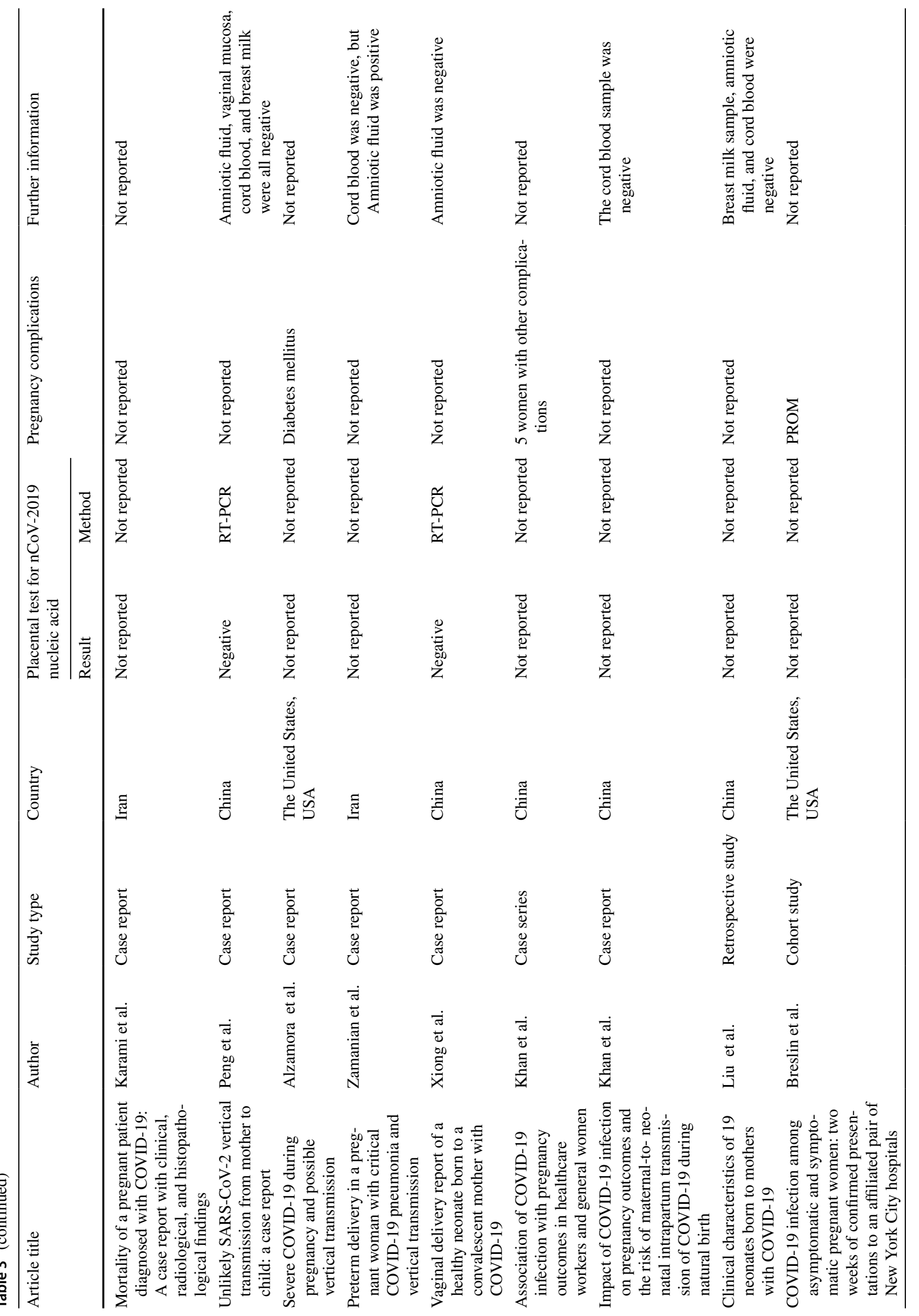




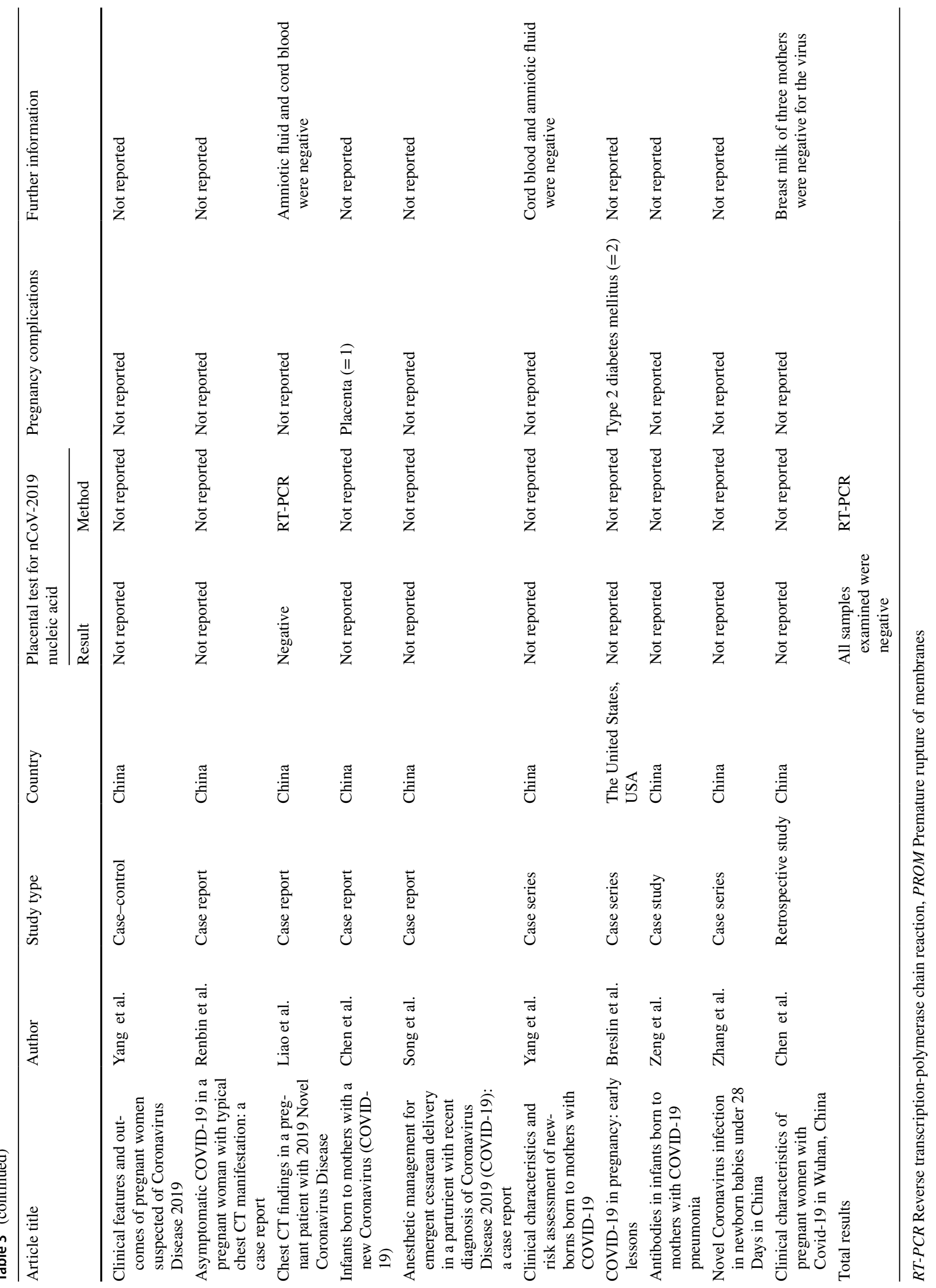


included myalgia, diarrhea, dyspnea, headache, and chest tightness. There were two women with specific presentations: one with Cholecystitis [50] and another with oil intolerance [67].

For nearly all pregnant women, the diagnosis was made based on a combination of clinical symptoms, nucleic acid testing for the novel coronavirus, and computed tomography (CT). As for the general population, some pregnant patients $(n=44)$ had a negative SARS-CoV-2 test but displayed clinical manifestations and abnormalities in CT scan related to COVID-19 [50, 53, 55].

Twenty-two (6.0\%) pregnant patients developed severe pneumonia. Among them, 10 cases $(2.8 \%)$ required mechanical ventilation and therefore were admitted to the intensive care unit (ICU) [42, 44, 53, 58, 60, 63, 65, 73, 74]. Two of these ten patients died from severe pneumonia and multiple organ dysfunction $[65,73]$.

The vast majority of patients were in their third trimester of pregnancy, and only 45 cases were in the first or second trimester (12.4\%). Of the total number of 299 births, there were $257(86 \%)$ cesarean sections, and $42(14 \%)$ vaginally completed. Zhang $\mathrm{L}$ et al. and Breslin et al. reported obstetric reasons such as premature rupture of membrane, fetal distress, and other indications for the Cesarean section [44, $60]$. Chen et al. reported that 38 of 63 cases who underwent cesarean sections claimed to have a fear of COVID19 [53]. There were three cases of spontaneous abortions, two ectopic pregnancy, and four induced abortions. Pregnant women seeking induced abortion were most afraid of COVID-19 and its potential effects on pregnancy outcomes [53].

\section{Neonatal outcomes}

Thirty-seven studies included a total of 302 neonates from mothers with COVID-19. Two studies have not indicated the timing of birth $[43,57]$. Of the studies that provided data, there were 210 full-term and 65 preterm neonates.

Karami et al. reported the death of a mother from COVID-19 and also her fetus [65]. The dead baby was born with an Apgar score of 0, did not respond to resuscitation, and was not considered for COVID-19 diagnostic tests. Of the babies born alive from mothers with COVID-19, five newborns faced critical conditions. One of them presented with a fast heart rate developed gastric bleeding and refractory shock later and died. The second complicated case was a premature newborn born from a mother, who had a diagnosis of severe COVID-19 pneumonia [50]. This neonate showed shortness of breath at presentation and developed disseminated intravascular coagulation (DIC). This case could be cured. The third neonate died due to the multiple organ dysfunction syndrome and could not survive [58]. The nasopharyngeal samples of these three babies were all negative for SARS-CoV-2 RNA detection. The fourth one suffered from pneumonia and needed intubation at birth. Sixteen hours after birth, the neonate tested positive for SARS-CoV-2 RNA with throat swab nucleic acid testing [74]. This neonate was later extubated and discharged without any complications. The fifth one was a premature baby with the gestational age of 31 weeks and 2 days. This neonate had an Apgar score of 3, 4, and 4 at the first, fifth, and tenth minute after delivery and required resuscitation [66]. This neonate was later confirmed as a definite case of COVID-19 and developed DIC. Vital signs were successfully stabilized on the day of 14 . This neonate had close contact with the mother after delivery.

Except for the babies mentioned above, most babies born alive had a 5-min Apgar score of 8 and 9 (Table 2). A total of 219 neonates underwent nasopharyngeal specimen collection for SARS-CoV-2 nucleic acid testing. Of them, 11 tested positive, and two of which were described above. A study by Wang $\mathrm{S}$ et al. reported a neonate with a positive throat specimen for COVID-19 [48]. This neonate had early close contact with COVID-19 positive mother, and the specimen was collected $36 \mathrm{~h}$ after birth, while the placental and cord blood specimens taken at birth were negative. Yu $\mathrm{N}$ et al. collected nasopharyngeal swab from three neonates, of which one was positive for COVID-19 [56]. This specimen was collected $36 \mathrm{~h}$ after birth, and that no nucleic acid testing was performed for the placenta, cord blood, or other pregnancy products.

In a cohort study of 33 neonates, there were two neonates with a positive test [66]. Both neonates survived. None of the placenta, cord blood, and other pregnancy products were tested for COVID-19 in this study. Zamanian et al. reported another newborn with a positive test who had fever without any further complications. By the end of the study, the neonate was healthy and stable [73]. Also, the other four COVID-19 positive neonates did not develop any complications and survived [46]. Seventeen studies reported the collection of the amniotic fluid, cord blood, placenta, and breast milk samples, and all tested negative except one amniotic fluid sample. Zamanyan et al. reported a pregnant woman with COVID-19 infection and her positive newborn. Nucleic acid testing was done on the cord blood and amniotic fluid samples [73]. Whereas no viral RNA was detected in the cord blood, the amniotic fluid was positive for viral RNA.

\section{Pregnancy outcomes}

In a case-control study by Zhang et al., there was no difference between 16 pregnant women with COVID-19 and 45 pregnant women without COVID-19 in terms of pregnancy complications, including eclampsia, fetal distress, and premature rupture of membrane (Table 3) [44]. 


\section{Discussion}

This systematic review included 386 pregnant women with COVID-19. There were 257 cesarean sections and 42 vaginal delivery. This relatively higher rate of cesarean sections would reflect the existence of indications for a cesarean section as well as the role of fear of vertical transmission. Most women represented common symptoms, and two deaths occurred (death rate of $0.5 \%$ ). While COVID-19 has, to date, caused a total number of 163,097 deaths out of 2.4 million confirmed cases, corresponding to the mortality rate of about $7 \%$ [77]. Therefore, compared to the general population, pregnant women have not shown a more aggressive form of COVID-19.

Among the total number of 302 neonates from mothers with COVID-19, there were nasopharyngeal specimens collected from 219 neonates, of which 11 tested positives for SARS-CoV-2. One study reported a positive SARSCoV-2 for amniotic fluid samples [73]. Interestingly, two studies reported high IgM levels in neonates who tested negative for SARS-CoV2 [43, 69]. Because there is no possibility of IgM transfer through the placenta, this laboratory data can be suggestive of vertical transmission of COVID-19. More studies are required to investigate the potential of COVID-19 to be transmitted via the vaginal route and the possible association between maternal infection with COVID-19 and long-term child health.

Nearly all mothers were healthy women without underlying severe diseases such as diabetes mellitus, cardiovascular disease, and autoimmune diseases. Therefore, further research is necessary to evaluate whether or not ethnicity/ race, maternal comorbidities, and pregnancy stage would influence the course of COVID-19 in pregnancy and how this, in turn, would affect delivery complications.

Finally, one crucial issue which remained unresolved is the psychosocial effects of the COVID-19 outbreak on mental health during pregnancy. Pregnant women frequently report psychosocial stress, depression, and panic disorder. In particular, there is a direct correlation between the level of antenatal psychosocial stress and the risk of poor pregnancy outcomes in the manner that the higher the antenatal psychosocial stress, the greater the risk of poor pregnancy outcomes. Therefore, pregnancy might be complicated during the COVID-19 outbreak, even if women do not get infected by the virus.

In this study, from 386 parturient women with COVID19,257 out of 299 patients gave birth by cesarean section, which means the cesarean section rate among these patients was about to $86 \%$, which is very high. In a national cohort study reported by Knight et al., the cesarean rate in pregnant women with COVID-19 in the United Kingdom was about 59\% [78]. In Germany, the CRONOS register website established to gather comprehensive data on mothers with COVID-19 who give birth around this country reports cesarean rate as about $37.5 \%$ by the last of January 2021 [79]. These national reports come from two highly developed countries equipped with the best available strategies to control the COVID-19 and related stress. It may positively impact pregnant women's psychological status when choosing delivery method. Another possible reason for the difference in results is the method of data gathering. This study is a systematic review including studies pertinent to different countries. At the time of systematic search by the last of April 2020, many studies reporting pregnant women with COVID-19 were case reports, case series, or studies with a low sample size. Still, the two mentioned studied were at a grander scale, which may effectuate the result. On the other hand, in our study, there is no patient from England or Germany, and most of the patients are from China. Although the CRONOS register is a large-scale registry, it lacks clinically important details, such as signs, symptoms, and history, about every individual registered in this program.

Since December 2019, COVID-19 has been a resident of the world. Early efforts ranged from the development of diagnostic assays [80-83] and specific therapeutics [84-102] to optimizing health monitoring [103, 104]. Despite this effort, in addition to our knowledge and experience from the recent outbreaks [105], it mainly relied on non-pharmacological interventions to control the pandemic, e.g., quarantine and social isolation $[106,107]$. Such a condition triggers stress [108]. The stress was, in particular, of high level at the time when the outbreak was initiated. Growing knowledge about different aspects of the disease, namely about the origin and pathogenesis of disease varying dependent on the immunogenetic background and the presence of comorbidities [4, 109-120], could protect against the stress and related damage, which is potentially critical in pregnant women and their neonates. Our review included studies conducted in the first six months of the pandemic when there was a high degree of stress and fear. This explains why the cesarean rate we calculated is relatively high, and also one can simply predict its reduction over time.

A major limitation is the lack of data in developing countries. Perinatal care is a crucial issue in less developed countries, while pregnant women in these countries may not have feasible access to health care facilities. Besides, insufficient perinatal care leads to a high rate of perinatal adverse events [122] while worsening during the pandemic. It is, therefore, important to gather enough data on pregnant women and their neonates in these countries. However, when this study was carried out, the data on less developed countries were too scarce, which may be because of lack of diagnostic facilities in these countries, insufficient referring, or reporting system. So further investigations are necessary to discover 
the impact of COVID-19 on perinatal events in developing countries.

\section{Conclusion}

The present systematic review suggests that clinical features and prognosis of pregnant women with COVID-19 may not be worse than the general population as well as some previous studies [121]. Still, this result should not lead to pregnant women ignore their suspect signs and symptoms to present themselves to medical care centers. It is crucial to provide optimum health care for pregnant women during the COVID-19 pandemic and follow their health status, especially respiratory signs and symptoms. The current evidence suggests that clinical features, diagnosis, and prognosis of COVID-19 in pregnant women are not different from those of the disease reported in society. Despite the high rate of contagion of COVID-19, vertical transmission of the novel coronavirus may remain a missing piece of the puzzle due to a lack of sufficient evidence. International collaboration remains a fundamental component of any future attempt to solve the puzzle [123-127].

Author contributions MM: Conceptualized the study, conducted database search, search results screening, detailed review, and prepared the initial draft. AS: Prepared the final draft. NR: Supervised the project and critically appraised the manuscript. All authors have read and approved the manuscript.

\section{Declarations}

Conflict of interest The authors declare that they have co conflicts of interest.

\section{References}

1. Hanaei S, Rezaei N (2020) COVID-19: developing from an outbreak to a pandemic. Arch Med Res 51(6):582-584. https://doi. org/10.1016/j.arcmed.2020.04.021

2. Baud D, Qi X, Nielsen-Saines K, Musso D, Pomar L, Favre G (2020) Real estimates of mortality following COVID-19 infection. Lancet Infect Dis 20(7):773

3. Hessami A, Shamshirian A, Heydari K, Pourali F, Alizadeh-Navaei R, Moosazadeh M, Abrotan S, Shojaie L, Sedighi S, Shamshirian D, Rezaei N (2020) Cardiovascular diseases burden in COVID-19: systematic review and meta-analysis. Am J Emerg Med. https://doi.org/10.1016/j.ajem.2020.10.022

4. Jabalameli N, Rajabi F, Firooz A, Rezaei N (2021) The overlap between genetic susceptibility to COVID-19 and skin diseases. Immunol Invest. https://doi.org/10.1080/08820139.2021.18760 86

5. Jahanshahlu L, Rezaei N (2020) Central nervous system involvement in COVID-19. Arch Med Res 51(7):721-722. https://doi. org/10.1016/j.arcmed.2020.05.016
6. Nejadghaderi SA, Heidari A, Shakerian N, Saghazadeh A, Rezaei N (2020) Cardiovascular system is at higher risk of affecting by COVID-19. Acta Biomed 91(3):e2020018. https:// doi.org/10.23750/abm.v91i3.9718

7. Saleki K, Banazadeh M, Saghazadeh A, Rezaei N (2020) The involvement of the central nervous system in patients with COVID-19. Rev Neurosci 31(4):453-456. https://doi.org/10. 1515/revneuro-2020-0026

8. Vakhshoori M, Heidarpour M, Shafie D, Taheri M, Rezaei N, Sarrafzadegan N (2020) Acute cardiac injury in COVID19: a systematic review and meta-analysis. Arch Iran Med 23(11):801-812. https://doi.org/10.34172/aim.2020.107

9. Yazdanpanah N, Saghazadeh A, Rezaei N (2020) Anosmia: a missing link in the neuroimmunology of coronavirus disease 2019 (COVID-19). Rev Neurosci 31(7):691-701. https://doi. org/10.1515/revneuro-2020-0039

10. Heidarpour M, Vakhshoori M, Abbasi S, Shafie D, Rezaei N (2020) Adrenal insufficiency in coronavirus disease 2019: a case report. J Med Case Rep 14(1):134. https://doi.org/10. 1186/s13256-020-02461-2

11. Goudarzi S, Dehghani Firouzabadi F, Dehghani Firouzabadi M, Rezaei N (2020) Cutaneous lesions and COVID-19: cystic painful lesion in a case with positive SARS-CoV-2. Dermatol Ther 33(6):e14266. https://doi.org/10.1111/dth.14266

12. Huang C, Wang Y, Li X, Ren L, Zhao J, Hu Y, Zhang L, Fan G, Xu J, Gu X (2020) Clinical features of patients infected with 2019 novel coronavirus in Wuhan, China. Lancet 395(10223):497-506

13. Aleebrahim-Dehkordi E, Soveyzi F, Deravi N, Rabbani Z, Saghazadeh A, Rezaei N (2021) Human Coronaviruses SARS-CoV, MERS-CoV, and SARS-CoV-2 in children. J Pediatr Nurs 56:70 79. https://doi.org/10.1016/j.pedn.2020.10.020

14. Lotfi M, Hamblin MR, Rezaei N (2020) COVID-19: transmission, prevention, and potential therapeutic opportunities. Clin Chim Acta 508:254-266. https://doi.org/10.1016/j.cca.2020.05. 044

15. Lotfi M, Rezaei N (2020) SARS-CoV-2: a comprehensive review from pathogenicity of the virus to clinical consequences. J Med Virol 92(10):1864-1874. https://doi.org/10.1002/jmv.26123

16. Rokni M, Hamblin MR, Rezaei N (2020) Cytokines and COVID19: friends or foes? Hum Vaccin Immunother 16(10):2363-2365. https://doi.org/10.1080/21645515.2020.1799669

17. Yazdanpanah F, Hamblin MR, Rezaei N (2020) The immune system and COVID-19: friend or foe? Life Sci 256:117900. https:// doi.org/10.1016/j.lfs.2020.117900

18. Ahanchian H, Moazzen N, Joghatayi SH, Saeidinia A, Khoshkhui M, Aelami MH, Rezaei N, Haghi NSM (2020) Death due to COVID-19 in an infant with combined immunodeficiencies. Endocr Metab Immune Disord Drug Targets. https://doi.org/10. 2174/1871530320666201021142313

19. Babaha F, Rezaei N (2020) Primary immunodeficiency diseases in COVID-19 pandemic: a predisposing or protective factor? Am J Med Sci 360(6):740-741. https://doi.org/10.1016/j.amjms. 2020.07.027

20. Bahrami A, Vafapour M, Moazzami B, Rezaei N (2020) Hyperinflammatory shock related to COVID-19 in a patient presenting with multisystem inflammatory syndrome in children: first case from Iran. J Paediatr Child Health. https://doi.org/10.1111/jpc. 15048

21. Delavari S, Abolhassani H, Abolnezhadian F, Babaha F, Iranparast S, Ahanchian H, Moazzen N, Nabavi M, Arshi S, Fallahpour M, Bemanian MH, Shokri S, Momen T, Sadeghi-Shabestari M, Molatefi R, Shirkani A, Vosughimotlagh A, Safarirad M, Sharifzadeh M, Pashangzadeh S, Salami F, Shirmast P, Rezaei A, Moeini Shad T, Mohraz M, Rezaei N, Hammarström L, Yazdani R, Aghamohamamdi A (2021) 
Impact of SARS-CoV-2 pandemic on patients with primary immunodeficiency. J Clin Immunol 41(2):345-355. https://doi. org/10.1007/s10875-020-00928-x

22. Khosroshahi LM, Rezaei N (2020) Dysregulation of the immune response in COVID-19. Cell Biol Int. https://doi.org/10.1002/ cbin. 11517

23. Saghazadeh A, Rezaei N (2020) Immune-epidemiological parameters of the novel coronavirus - a perspective. Expert Rev Clin Immunol 16(5):465-470. https://doi.org/10.1080/1744666x. 2020.1750954

24. Torabi-Rahvar M, Rezaei N (2020) Storm at the time of Corona: a glimpse at the current understanding and therapeutic opportunities of the SARS-CoV-2 cytokine storm. Curr Pharm Des. https:// doi.org/10.2174/1381612826666201125102649

25. Mojtabavi H, Saghazadeh A, Rezaei N (2020) Interleukin-6 and severe COVID-19: a systematic review and meta-analysis. Eur Cytokine Netw 31(2):44-49. https://doi.org/10.1684/ecn.2020. 0448

26. Sarzaeim M, Rezaei N (2020) Kawasaki disease and multisystem inflammatory syndrome in children with COVID-19. SN Compr Clin Med. https://doi.org/10.1007/s42399-020-00558-9

27. Nasab MG, Saghazadeh A, Rezaei N (2020) SARS-CoV2-A tough opponent for the immune system. Arch Med Res 51(6):589-592. https://doi.org/10.1016/j.arcmed.2020.05.020

28. Yang H, Wang C, Poon LC (2020) Novel coronavirus infection and pregnancy. Ultrasound Obstet Gynecol 55(4):435-437

29. Rezaei N (2020) COVID-19 affects healthy pediatricians more than pediatric patients. Infect Control Hosp Epidemiol 41(9):1106-1107. https://doi.org/10.1017/ice.2020.139

30. Favre G, Pomar L, Musso D, Baud D (2020) 2019-nCoV epidemic: what about pregnancies? Lancet 395(10224):e40. https:// doi.org/10.1016/S0140-6736(20)30311-1

31. Ashokka B, Loh M-H, Tan CH, Su LL, Young BE, Lye DC, Biswas A, Illanes E, S, Choolani M, (2020) Care of the pregnant woman with COVID-19 in labor and delivery: anesthesia, emergency cesarean delivery, differential diagnosis in the acutely ill parturient, care of the newborn, and protection of the healthcare personnel. Am J Obstet Gynecol 223(1):66

32. Dashraath P, Jing Lin Jeslyn W, Mei Xian Karen L, Li Min L, Sarah L, Biswas A, Arjandas Choolani M, Mattar C, Lin SL (2020) Coronavirus disease 2019 (COVID-19) pandemic and pregnancy. Am J Obstet Gynecol 41:7

33. Mayor S (2020) Covid-19: Nine in 10 pregnant women with infection when admitted for delivery are asymptomatic, small study finds. BMJ 369:m1485. https://doi.org/10.1136/bmj.m1485

34. Schwartz DA, Graham AL (2020) Potential maternal and infant outcomes from (Wuhan) Coronavirus 2019-nCoV infecting pregnant women: lessons from SARS, MERS, and other human coronavirus infections. Viruses. https://doi.org/10.3390/v1202 0194

35. Omer S, Ali S, Babar ZUD (2020) Preventive measures and management of COVID-19 in pregnancy. Drugs Ther Perspect. https://doi.org/10.1007/s40267-020-00725-x

36. Wu X, Sun R, Chen J, Xie Y, Zhang S, Wang X (2020) Radiological findings and clinical characteristics of pregnant women with COVID-19 pneumonia. Int J Gynaecol Obstet. https://doi. org/10.1002/ijgo.13165

37. Wen R, Sun P, Xing Q-S (2020) A patient with SARS-CoV-2 infection during pregnancy in Qingdao, China. J Microbiol Immunol Infect. https://doi.org/10.1016/j.jmii.2020.03.004

38. Vlachodimitropoulou Koumoutsea E, Vivanti AJ, Shehata N, Benachi A, Le Gouez A, Desconclois C, Whittle W, Snelgrove J, Malinowski KA (2020) COVID19 and acute coagulopathy in pregnancy. J Thromb Haemost. https://doi.org/10.1111/jth.14856

39. Zeng LK, Tao XW, Yuan WH, Wang J, Liu X, Liu ZS (2020) First case of neonate infected with novel coronavirus pneumonia in China. Zhonghua Er Ke Za Zhi 58:E009. https:// doi.org/10.3760/cma.j.issn.0578-1310.2020.0009

40. Schwartz DA (2020) An analysis of 38 pregnant women with COVID-19, their newborn infants, and maternal-fetal transmission of SARS-CoV-2: maternal coronavirus infections and pregnancy outcomes. Arch Pathol Lab Med. https://doi.org/10. 5858/arpa.2020-0901-SA

41. Lei D, Wang C, Li C, Fang C, Yang W, Chen B, Wei M, Xu X, Yang H, Wang S, Fan C (2020) Clinical characteristics of COVID-19 in pregnancy: analysis of nine cases. Chin J Perinat Med 23(3):159-165

42. Breslin N, Baptiste C, Miller R, Fuchs K, Goffman D, GyamfiBannerman C, D'Alton M (2020) COVID-19 in pregnancy: early lessons. Am J Obstet Gynecol. https://doi.org/10.1016/j. ajogmf.2020.100111

43. Zeng H, Xu C, Fan J, Tang Y, Deng Q, Zhang W, Long X (2020) Antibodies in infants born to mothers With COVID-19 Pneumonia. JAMA. https://doi.org/10.1001/jama.2020.4861

44. Zhang L, Jiang Y, Wei M, Cheng BH, Zhou XC, Li J, Tian JH, Dong L, Hu RH (2020) Analysis of the pregnancy outcomes in pregnant women with COVID-19 in Hubei Province. Zhonghua Fu Chan Ke Za Zhi 55:E009. https://doi.org/10.3760/cma.j. cn112141-20200218-00111

45. Song L, Xiao W, Ling K, Yao S, Chen X (2020) Anesthetic management for emergent cesarean delivery in a parturient with recent diagnosis of Coronavirus Disease 2019 (COVID19): a case report. Transl Perioper Pain Med. https://doi.org/ $10.31480 / 2330-4871 / 118$

46. Khan S, Jun L, Nawsherwan SR, Li Y, Han G, Xue M, Nabi G, Liu J (2020) Association of COVID-19 infection with pregnancy outcomes in healthcare workers and general women. Clin Microbiol Infect. https://doi.org/10.1016/j.cmi.2020.03. 034

47. Li Y, Zhao R, Zheng S, Chen X, Wang J, Sheng X, Zhou J, Cai H, Fang Q, Yu F, Fan J, Xu K, Chen Y, Sheng J (2020) Lack of vertical transmission of severe acute respiratory syndrome Coronavirus 2, China. Emerg Infect Dis. https://doi.org/10. 3201/eid2606.200287

48. Wang X, Zhou Z, Zhang J, Zhu F, Tang Y, Shen X (2020) A case of 2019 Novel Coronavirus in a pregnant woman with preterm delivery. Clin Infect Dis. https://doi.org/10.1093/cid/ ciaa200

49. Liao X, Yang H, Kong J, Yang H (2020) Chest CT findings in a pregnant patient with 2019 Novel Coronavirus. Balkan Med J 37(4):226-228

50. Zhu H, Wang L, Fang C, Peng S, Zhang L, Chang G, Xia S, Zhou W (2020) Clinical analysis of 10 neonates born to mothers with 2019-nCoV pneumonia. Transl Pediatr 9(1):51-60. https://doi. org/10.21037/tp.2020.02.06

51. Chen S, Liao E, Shao Y (2020) Clinical analysis of pregnant women with 2019 novel coronavirus pneumonia. J Med Virol. https://doi.org/10.1002/jmv.25789

52. Chen H, Guo J, Wang C, Luo F, Yu X, Zhang W, Li J, Zhao D, Xu D, Gong Q, Liao J, Yang H, Hou W, Zhang Y (2020) Clinical characteristics and intrauterine vertical transmission potential of COVID-19 infection in nine pregnant women: a retrospective review of medical records. Lancet 395(10226):809-815. https:// doi.org/10.1016/s0140-6736(20)30360-3

53. Chen L, Li Q, Zheng D, Jiang H, Wei Y, Zou L, Feng L, Xiong G, Sun G, Wang H, Zhao Y, Qiao J (2020) Clinical characteristics of pregnant women with Covid-19 in Wuhan, China. N Engl J Med. https://doi.org/10.1056/NEJMc2009226

54. Yang P, Wang X, Liu P, Wei C, He B, Zheng J, Zhao D (2020) Clinical characteristics and risk assessment of newborns born to mothers with COVID-19. J Clin Virol 127:104356. https://doi. org/10.1016/j.jcv.2020.104356 
55. Liu W, Wang J, Li W, Zhou Z, Liu S, Rong Z (2020) Clinical characteristics of 19 neonates born to mothers with COVID-19. Front Med. https://doi.org/10.1007/s11684-020-0772-y

56. Yu N, Li W, Kang Q, Xiong Z, Wang S, Lin X, Liu Y, Xiao J, Liu H, Deng D, Chen S, Zeng W, Feng L, Wu J (2020) Clinical features and obstetric and neonatal outcomes of pregnant patients with COVID-19 in Wuhan, China: a retrospective, single-centre, descriptive study. Lancet Infect Dis 20(5):559-564

57. Sun G, Tang F, Peng M, Gao Y, Peng J, Xie H, Zhao Y, Jin $\mathrm{Z}$ (2020) Clinical Features and outcomes of pregnant women suspected of Coronavirus Disease 2019. J Infect 88(1):e40-e44

58. Liu Y, Chen H, Tang K, Guo Y (2020) Clinical manifestations and outcome of SARS-CoV-2 infection during pregnancy. $\mathrm{J}$ Infect. https://doi.org/10.1016/j.jinf.2020.02.028

59. Liu W, Wang Q, Zhang Q, Chen L, Chen J, Zhang B, Lu Y, Wang S, Xia L, Huang L, Wang K, Liang L, Zhang Y, Turtle L, LissauerD, Lan K, Feng L, Yu H, Liu Y, Sun Z (2020) Coronavirus disease 2019 (COVID-19) during pregnancy: a case series. https://www.preprints.org/manuscript/202002.0373/v1

60. Breslin N, Baptiste C, Gyamfi-Bannerman C, Miller R, Martinez R, Bernstein K, Ring L, Landau R, Purisch S, Friedman AM, Fuchs K, Sutton D, Andrikopoulou M, Rupley D, Sheen JJ, Aubey J, Zork N, Moroz L, Mourad M, Wapner R, Simpson LL, D'Alton ME, Goffman D (2020) COVID-19 infection among asymptomatic and symptomatic pregnant women: two weeks of confirmed presentations to an affiliated pair of New York City hospitals. Am J Obstet Gynecol. https://doi.org/10. 1016/j.ajogmf.2020.100118

61. Khan S, Peng L, Siddique R, Nabi G, Nawsherwan u, Xue M, Liu J, Han G, (2020) Impact of COVID-19 infection on pregnancy outcomes and the risk of maternal-to-neonatal intrapartum transmission of COVID-19 during natural birth. Infect Control Hospital Epidemiol. https://doi.org/10.1017/ice.2020. 84

62. Chen D, Xu W, Lei Z, Huang Z, Liu J, Gao Z, Peng L (2020) Recurrence of positive SARS-CoV-2 RNA in COVID-19: a case report. Int J Infect Dis 93:297-299. https://doi.org/10.1016/j.ijid. 2020.03.003

63. Kalafat E, Yaprak E, Cinar G, Varli B, Ozisik S, Uzun C, Azap A, Koc A (2020) Lung ultrasound and computed tomographic findings in pregnant woman with COVID-19. Ultrasound in Obstetrics Gynecology 55(6):835-837

64. Li N, Han L, Peng M, Lv Y, Ouyang Y, Liu K, Yue L, Li Q, Sun G, Chen L, Yang L (2020) Maternal and neonatal outcomes of pregnant women with COVID-19 pneumonia: a case-control study. Clin Infect Dis. https://doi.org/10.1093/cid/ciaa352

65. Karami P, Naghavi M, Feyzi A, Aghamohammadi M, Novin MS, Mobaien A, Qorbanisani M, Karami A, Norooznezhad AH (2020) Mortality of a pregnant patient diagnosed with COVID19: a case report with clinical, radiological, and histopathological findings. Travel Med Infect Dis. https://doi.org/10.1016/j.tmaid. 2020.101665

66. Zeng L, Xia S, Yuan W, Yan K, Xiao F, Shao J, Zhou W (2020) Neonatal early-onset infection With SARS-CoV-2 in 33 neonates born to mothers with COVID-19 in Wuhan, China. JAMA Pediatr. https://doi.org/10.1001/jamapediatrics.2020.0878

67. Zhang ZJ, Yu XJ, Fu T, Liu Y, Jiang Y, Yang BX, Bi Y (2020) Novel Coronavirus infection in newborn babies under 28 days in China. Eur Respir J. https://doi.org/10.1183/13993003. 00697-2020

68. Fan C, Lei D, Fang C, Li C, Wang M, Liu Y, Bao Y, Sun Y, Huang J, Guo Y, Yu Y, Wang S (2020) Perinatal transmission of COVID-19 associated SARS-CoV-2: should we worry? Clin Infect Dis. https://doi.org/10.1093/cid/ciaa226

69. Dong L, Tian J, He S, Zhu C, Wang J, Liu C, Yang J (2020) Possible vertical transmission of SARS-CoV-2 from an infected mother to her newborn. JAMA. https://doi.org/10.1001/jama. 2020.4621

70. Liu D, Li L, Wu X, Zheng D, Wang J, Yang L, Zheng C (2020) Pregnancy and Perinatal outcomes of women with Coronavirus Disease (COVID-19) Pneumonia: a preliminary analysis. Am J Roentgenol. https://doi.org/10.2214/AJR.20.23072

71. Zambrano LI, Fuentes-Barahona IC, Bejarano-Torres DA, Bustillo C, Gonzales G, Vallecillo-Chinchilla G, SanchezMartinez FE, Valle-Reconco JA, Sierra M, Bonilla-Aldana DK, Cardona-Ospina JA, Rodriguez-Morales AJ (2020) A pregnant woman with COVID-19 in Central America. Travel Med Infect Dis. https://doi.org/10.1016/j.tmaid.2020.101639

72. Chen S, Huang B, Luo DJ, Li X, Yang F, Zhao Y, Nie X, Huang BX (2020) Pregnant women with new coronavirus infection: a clinical characteristics and placental pathological analysis of three cases. Zhonghua Bing Li Xue Za Zhi 49:E005. https://doi. org/10.3760/cma.j.cn112151-20200225-00138

73. Zamaniyan M, Ebadi A, Aghajanpoor Mir S, Rahmani Z, Haghshenas M, Azizi S (2020) Preterm delivery in pregnant woman with critical COVID-19 pneumonia and vertical transmission. Prenat Diagn. https://doi.org/10.1002/pd.5713

74. Alzamora MC, Paredes T, Caceres D, Webb CM, Valdez LM, La Rosa M (2020) Severe COVID-19 during pregnancy and possible vertical transmission. Am J Perinatol. https://doi.org/10.1055/s0040-1710050

75. Peng Z, Wang J, Mo Y, Duan W, Xiang G, Yi M, Bao L, Shi Y (2020) Unlikely SARS-CoV-2 vertical transmission from mother to child: A case report. J Infect Public Health. https://doi.org/10. 1016/j.jiph.2020.04.004

76. Xiong X, Wei H, Zhang Z, Chang J, Ma X, Gao X, Chen Q, Pang Q (2020) Vaginal delivery report of a healthy neonate born to a convalescent mother with COVID-19. J Med Virol. https://doi. org/10.1002/jmv.25857

77. (WHO) WHO (2020) WHO COVID-19 Dashboard. https://covid 19.who.int. Accessed 21 Apr 2020

78. Knight M, Bunch K, Vousden N, Morris E, Simpson N, Gale C, O’Brien P, Quigley M, Brocklehurst P, Kurinczuk JJ (2020) Characteristics and outcomes of pregnant women admitted to hospital with confirmed SARS-CoV-2 infection in UK: national population based cohort study. BMJ 369:m2107. https://doi.org/ 10.1136/bmj.m2107

79. CRONOS Register. https://www.dgpm-online.org/index.php?id= 60

80. Basiri A, Heidari A, Nadi MF, Fallahy MTP, Nezamabadi SS, Sedighi M, Saghazadeh A, Rezaei N (2021) Microfluidic devices for detection of RNA viruses. Rev Med Virol 31(1):1-11. https:// doi.org/10.1002/rmv.2154

81. Rabiee N, Rabiee M, Bagherzadeh M, Rezaei N (2020) COVID19 and picotechnology: Potential opportunities. Med Hypotheses 144:109917. https://doi.org/10.1016/j.mehy.2020.109917

82. Tantuoyir MM, Rezaei N (2020) Serological tests for COVID19: potential opportunities. Cell Biol Int. https://doi.org/10.1002/ cbin. 11516

83. Jabbari P, Rezaei N (2020) With risk of reinfection, is COVID-19 here to stay? Disaster Med Public Health Prep 14(4):e33. https:// doi.org/10.1017/dmp.2020.274

84. Basiri A, Pazhouhnia Z, Beheshtizadeh N, Hoseinpour M, Saghazadeh A, Rezaei N (2020) Regenerative medicine in COVID19 treatment: real opportunities and range of promises. Stem Cell Rev Rep. https://doi.org/10.1007/s12015-020-09994-5

85. Jahanshahlu L, Rezaei N (2020) Monoclonal antibody as a potential anti-COVID-19. Biomed Pharmacother 129:110337. https:// doi.org/10.1016/j.biopha.2020.110337

86. Lotfi M, Rezaei N (2020) CRISPR/Cas13: a potential therapeutic option of COVID-19. Biomed Pharmacother 131:110738. https:// doi.org/10.1016/j.biopha.2020.110738 
87. Mansourabadi AH, Sadeghalvad M, Mohammadi-Motlagh HR, Rezaei N (2020) The immune system as a target for therapy of SARS-CoV-2: a systematic review of the current immunotherapies for COVID-19. Life Sci 258:118185. https://doi.org/10. 1016/j.lfs.2020.118185

88. Mohamed K, Yazdanpanah N, Saghazadeh A, Rezaei N (2021) Computational drug discovery and repurposing for the treatment of COVID-19: a systematic review. Bioorg Chem 106:104490. https://doi.org/10.1016/j.bioorg.2020.104490

89. Moradian N, Gouravani M, Salehi MA, Heidari A, Shafeghat M, Hamblin MR, Rezaei N (2020) Cytokine release syndrome: inhibition of pro-inflammatory cytokines as a solution for reducing COVID-19 mortality. Eur Cytokine Netw 31(3):81-93. https:// doi.org/10.1684/ecn.2020.0451

90. Palit P, Chattopadhyay D, Thomas S, Kundu A, Kim HS, Rezaei N (2020) Phytopharmaceuticals mediated Furin and TMPRSS2 receptor blocking: can it be a potential therapeutic option for Covid-19? Phytomedicine. https://doi.org/10.1016/j.phymed. 2020.153396

91. Peymani P, Dehesh T, Aligolighasemabadi F, Sadeghdoust M, Kotfis K, Ahmadi M, Mehrbod P, Iranpour P, Dastghaib S, Nasimian A, Ravandi A, Kidane B, Ahmed N, Sharma P, Shojaei S, Bagheri Lankarani K, Madej A, Rezaei N, Madrakian T, Los MJ, Labouta HI, Mokarram P, Ghavami S (2021) Statins in patients with COVID-19: a retrospective cohort study in Iranian COVID-19 patients. Transl Med Commun 6(1):3. https://doi.org/ 10.1186/s41231-021-00082-5

92. Pourahmad R, Moazzami B, Rezaei N (2020) Efficacy of plasmapheresis and immunoglobulin replacement therapy (IVIG) on patients with COVID-19. SN Compr Clin Med. https://doi.org/ 10.1007/s42399-020-00438-2

93. Saghazadeh A, Rezaei N (2020) Towards treatment planning of COVID-19: rationale and hypothesis for the use of multiple immunosuppressive agents: anti-antibodies, immunoglobulins, and corticosteroids. Int Immunopharmacol 84:106560. https:// doi.org/10.1016/j.intimp.2020.106560

94. Seyedpour S, Khodaei B, Loghman AH, Seyedpour N, Kisomi MF, Balibegloo M, Nezamabadi SS, Gholami B, Saghazadeh A, Rezaei N (2020) Targeted therapy strategies against SARSCoV-2 cell entry mechanisms: a systematic review of in vitro and in vivo studies. J Cell Physiol. https://doi.org/10.1002/jcp.30032

95. Shojaeefar E, Malih N, Rezaei N (2021) The possible doubleedged sword effects of vitamin D on COVID-19: a hypothesis. Cell Biol Int 45(1):54-57. https://doi.org/10.1002/cbin.11469

96. Zarandi PK, Zinatizadeh MR, Zinatizadeh M, Yousefi MH, Rezaei N (2021) SARS-CoV-2: from the pathogenesis to potential anti-viral treatments. Biomed Pharmacother 137:111352. https://doi.org/10.1016/j.biopha.2021.111352

97. Fathi N, Rezaei N (2020) Lymphopenia in COVID-19: therapeutic opportunities. Cell Biol Int 44(9):1792-1797. https://doi.org/ 10.1002/cbin.11403

98. Pezeshki PS, Rezaei N (2021) Immune checkpoint inhibition in COVID-19: risks and benefits. Expert Opin Biol Ther. https:// doi.org/10.1080/14712598.2021.1887131

99. Rezaei N (2020) COVID-19 and medical biotechnology. Avicenna J Med Biotechnol 12(3):139

100. Sharifkashani S, Bafrani MA, Khaboushan AS, Pirzadeh M, Kheirandish A, Yavarpour Bali H, Hessami A, Saghazadeh A, Rezaei N (2020) Angiotensin-converting enzyme 2 (ACE2) receptor and SARS-CoV-2: potential therapeutic targeting. Eur J Pharmacol 884:173455. https://doi.org/10.1016/j.ejphar.2020. 173455

101. Torabi S, Bahreini F, Rezaei N (2020) The role of angiotensinconverting enzyme 2 in COVID-19 induced lung injury. Acta Biomed 91(4):e2020142. https://doi.org/10.23750/abm.v91i4. 10159
102. Pashaei M, Rezaei N (2020) Immunotherapy for SARS-CoV-2: potential opportunities. Expert Opin Biol Ther 20(10):11111116. https://doi.org/10.1080/14712598.2020.1807933

103. Moazzami B, Razavi-Khorasani N, Dooghaie Moghadam A, Farokhi E, Rezaei N (2020) COVID-19 and telemedicine: immediate action required for maintaining healthcare providers well-being. J Clin Virol 126:104345. https://doi.org/10.1016/j. jcv.2020.104345

104. Jabbari P, Taraghikhah N, Jabbari F, Ebrahimi S, Rezaei N (2020) Adherence of the general public to self-protection guidelines during the COVID-19 pandemic. Disaster Med Public Health Prep. https://doi.org/10.1017/dmp.2020.445

105. Jabbari P, Jabbari F, Ebrahimi S, Rezaei N (2020) COVID-19: a chimera of two pandemics. Disaster Med Public Health Prep 14(3):e38-e39. https://doi.org/10.1017/dmp.2020.223

106. Samieefar N, Yari Boroujeni R, Jamee M, Lotfi M, Golabchi MR, Afshar A, Miri H, Khazeei Tabari MA, Darzi P, Abdullatif Khafaie M, Amirheidari B, Tamadon A, Rambod Rad N, Samimi N, Farjam M, Shiravi F, Farshidi N, Hedayati ChM, Doostkamel D, Alikhani R, Razmkhah M, Abdollahifard S, Nasiri Kalmarzi R, Kelishadi R, Khazaei H, Aghamohammadi A, Jafari Mousavi FS, Shamsizadeh M, Khojasteh A, Rezaei N (2020) Country quarantine during COVID-19: critical or not? Disaster Med Public Health Prep. https://doi.org/10.1017/dmp.2020.384

107. Hanaei S, Takian A, Majdzadeh R, Maboloc CR, Grossmann I, Gomes O, Milosevic M, Gupta M, Shamshirsaz AA, Harbi A, Burhan AM, Uddin LQ, Kulasinghe A, Lam CM, Ramakrishna S, Alavi A, Nouwen JL, Dorigo T, Schreiber M, Abraham A, Shelkovaya N, Krysztofiak W, Ebrahimi Warkiani M, Sellke F, Ogino S, Barba FJ, Brand S, Vasconcelos C, Salunke DB, Rezaei N (2020) Emerging Standards and the hybrid model for organizing scientific events during and after the COVID-19 pandemic. Disaster Med Public Health Prep. https://doi.org/10.1017/dmp. 2020.406

108. Salehi M, Amanat M, Mohammadi M, Salmanian M, Rezaei N, Saghazadeh A, Garakani A (2021) The prevalence of posttraumatic stress disorder related symptoms in Coronavirus outbreaks: a systematic-review and meta-analysis. J Affect Disord 282:527-538. https://doi.org/10.1016/j.jad.2020.12.188

109. Darbeheshti F, Rezaei N (2020) Genetic predisposition models to COVID-19 infection. Med Hypotheses 142:109818. https:// doi.org/10.1016/j.mehy.2020.109818

110. Hassan SS, Ghosh S, Attrish D, Choudhury PP, Aljabali AAA, Uhal BD, Lundstrom K, Rezaei N, Uversky VN, Seyran M, Pizzol D, Adadi P, Soares A, El-Aziz TMA, Kandimalla R, Tambuwala MM, Azad GK, Sherchan SP, Baetas-da-Cruz W, Takayama K, Serrano-Aroca Á, Chauhan G, Palu G, Brufsky AM (2020) Possible transmission flow of SARS-CoV-2 based on ACE2 features. Molecules. https://doi.org/10.3390/molecules25245906

111. Lundstrom K, Seyran M, Pizzol D, Adadi P, Mohamed Abd ElAziz T, Hassan SS, Soares A, Kandimalla R, Tambuwala MM, Aljabali AAA, Kumar Azad G, Pal Choudhury P, Uversky VN, Sherchan SP, Uhal BD, Rezaei N, Brufsky AM (2020) Viewpoint: origin of SARS-CoV-2. Viruses. https://doi.org/10.3390/ v12111203

112. Seyran M, Pizzol D, Adadi P, El-Aziz TMA, Hassan SS, Soares A, Kandimalla R, Lundstrom K, Tambuwala M, Aljabali AAA, Lal A, Azad GK, Choudhury PP, Uversky VN, Sherchan SP, Uhal BD, Rezaei N, Brufsky AM (2020) Questions concerning the proximal origin of SARS-CoV-2. J Med Virol. https://doi. org/10.1002/jmv. 26478

113. Yousefzadegan S, Rezaei N (2020) Case report: death due to COVID-19 in three brothers. Am J Trop Med Hyg 102(6): 1203 1204. https://doi.org/10.4269/ajtmh.20-0240 
114. Khanmohammadi S, Rezaei N (2021) Role of Toll-like receptors in the pathogenesis of COVID-19. J Med Virol. https://doi.org/ 10.1002/jmv.26826

115. Razavi A, Hamblin MR, Rezaei N (2021) COVID-19 in patients with cancer: risks and precautions. Am J Emerg Med. https://doi. org/10.1016/j.ajem.2021.01.067

116. Safdarian AR, Momenzadeh K, Kahe F, Farhangnia P, Rezaei N (2020) Death due to COVID-19 in a patient with diabetes, epilepsy, and gout comorbidities. Clin Case Rep 9(1):461-464. https://doi.org/10.1002/ccr3.3557

117. Sadeghmousavi S, Rezaei N (2020) COVID-19 and multiple sclerosis: predisposition and precautions in treatment. SN Compr Clin Med. https://doi.org/10.1007/s42399-020-00504-9

118. Seyran M, Takayama K, Uversky VN, Lundstrom K, Palù G, Sherchan SP, Attrish D, Rezaei N, Aljabali AAA, Ghosh S, Pizzol D, Chauhan G, Adadi P, Mohamed Abd El-Aziz T, Soares AG, Kandimalla R, Tambuwala M, Hassan SS, Azad GK, Pal Choudhury P, Baetas-da-Cruz W, Serrano-Aroca Á, Brufsky AM, Uhal BD (2020) The structural basis of accelerated host cell entry by SARS-CoV-2†. FEBS J. https://doi.org/10.1111/ febs. 15651

119. Jenab Y, Rezaei N, Hedayat B, Naderian M, Shirani S, Hosseini K (2020) Occurrence of acute coronary syndrome, pulmonary thromboembolism, and cerebrovascular event in COVID-19. Clin Case Rep 8(12):2414-2417. https://doi.org/10.1002/ccr3.3112

120. Sahu KK, Siddiqui AD, Rezaei N, Cerny J (2020) Challenges for management of immune thrombocytopenia during COVID19 pandemic. J Med Virol 92(11):2277-2282. https://doi.org/10. 1002/jmv.26251

121. Figueiro-Filho EA, Yudin M, Farine D (2020) COVID-19 during pregnancy: an overview of maternal characteristics, clinical symptoms, maternal and neonatal outcomes of 10,996 cases described in 15 countries. J Perinat Med 48(9):900-911. https:// doi.org/10.1515/jpm-2020-0364

122. Zupan J (2005) Perinatal mortality in developing countries. $\mathrm{N}$ Engl J Med 352(20):2047-2048. https://doi.org/10.1056/NEJMp 058032

123. Mohamed K, Rezaei N, Rodríguez-Román E, Rahmani F, Zhang H, Ivanovska M, Makka SA, Joya M, Makuku R, Md Shahidul I, Nesrine R, Laila R, Goda R, Sunny OA, Mujtaba S, Zoghi S, Irtsyan S, Ling I, Orsolya C, Attig-Bahar F, Hazar Sayar E,
Soloukey C, Giulia G (2020) International efforts to save healthcare personnel during COVID-19. Acta Biomed 91(3):e2020044

124. Mohamed K, Rodríguez-Román E, Rahmani F, Zhang H, Ivanovska M, Makka SA, Joya M, Makuku R, Islam MS, Radwan N, Rahmah L, Goda R, Abarikwu SO, Shaw M, Zoghi S, Irtsyan S, Ling I, Cseprekal O, Faten AB, Hazar Sayar E, Soloukey C, Grancini G, Rezaei N (2020) Borderless collaboration is needed for COVID-19-A disease that knows no borders. Infect Control Hosp Epidemiol 41(10):1245-1246. https://doi.org/10.1017/ice. 2020.162

125. Momtazmanesh S, Ochs HD, Uddin LQ, Perc M, Routes JM, Vieira DN, Al-Herz W, Baris S, Prando C, Rosivall L, Abdul Latiff AH, Ulrichs T, Roudenok V, Aldave Becerra JC, Salunke DB, Goudouris E, Condino-Neto A, Stashchak A, Kryvenko O, Stashchak M, Bondarenko A, Rezaei N (2020) All together to Fight COVID-19. Am J Trop Med Hyg 102(6):1181-1183. https://doi.org/10.4269/ajtmh.20-0281

126. Moradian N, Ochs HD, Sedikies C, Hamblin MR, Camargo CA Jr, Martinez JA, Biamonte JD, Abdollahi M, Torres PJ, Nieto JJ, Ogino S, Seymour JF, Abraham A, Cauda V, Gupta S, Ramakrishna S, Sellke FW, Sorooshian A, Wallace Hayes A, Martinez-Urbistondo M, Gupta M, Azadbakht L, Esmaillzadeh A, Kelishadi R, Esteghamati A, Emam-Djomeh Z, Majdzadeh R, Palit P, Badali H, Rao I, Saboury AA, Jagan Mohan Rao L, Ahmadieh H, Montazeri A, Fadini GP, Pauly D, Thomas S, Moosavi-Movahed AA, Aghamohammadi A, Behmanesh M, Rahimi-Movaghar V, Ghavami S, Mehran R, Uddin LQ, Von Herrath M, Mobasher B, Rezaei N (2020) The urgent need for integrated science to fight COVID-19 pandemic and beyond. J Transl Med 18(1):205. https://doi.org/10.1186/ s12967-020-02364-2

127. Mohamed K, Rezaei N (2020) COVID-19 pandemic is not the time of trial and error. Am J Emerg Med. https://doi.org/10. 1016/j.ajem.2020.09.020

Publisher's Note Springer Nature remains neutral with regard to jurisdictional claims in published maps and institutional affiliations. 